Published in final edited form as:

Genesis. 2008 April ; 46(4): 214-228.

\title{
The Genetics of Essential Metal Homeostasis During
}

\section{Development}

\author{
Taiho Kambe, Benjamin P. Weaver, and Glen K. Andrews ${ }^{*}$ \\ Department of Biochemistry and Molecular Biology, University of Kansas Medical Center, Kansas \\ City, Kansas
}

\section{Summary}

The essential metals copper, zinc, and iron play key roles in embryonic, fetal, and postnatal development in higher eukaryotes. Recent advances in our understanding of the molecules involved in the intricate control of the homeostasis of these metals and the availability of natural mutations and targeted mutations in many of the genes involved have allowed for elucidation of the diverse roles of these metals during development. Evidence suggests that the ability of the embryo to control the homeostasis of these metals becomes essential at the blastocyst stage and during early morphogenesis. However, these metals play unique roles throughout development and exert pleiotropic, metalspecific, and often cell-specific effects on morphogenesis, growth, and differentiation. Herein, we briefly review the major players known to be involved in the homeostasis of each of these essential metals and their known roles in development.

\section{Keywords}

copper; development; genetics; homeostasis; iron; knockout mice; review; zinc

\section{REGULATION OF COPPER HOMEOSTASIS}

Copper plays a critical role in metabolism as a cofactor for several cupric enzymes, including cytochrome $c$ oxidase (CCO), lysyl oxidase, tyrosinase, copper/zinc superoxide dismutase (SOD1), and ferroxidases (Pena et al., 1999; Prohaska and Gybina, 2004; Shim and Harris, 2003). However, copper is a potentially toxic metal because of its ability to redox cycle and support Fenton chemistry leading to the production of free radicals (Halliwell and Gutteridge, 1984). Therefore, copper homeostasis is very tightly regulated (see Fig. 1). Copper deficiency stimulates the absorption of copper by the intestine (Kuo et al., 2001), but the mechanisms of uptake of dietary copper are not understood (Maryon et al., 2007). CTR1 (Slc31a1), a high affinity, trimeric copper transport protein, is essential for acquisition of dietary copper (Nose et al., 2006). CTR1 has been localized to basolateral and intracellular membranes of enterocytes in the adult (Kuo et al., 2006; Zimnicka et al., 2007), and thus does not appear to play a role in the uptake of dietary copper in the adult, although it has been localized to the apical surface of the enterocyte in the suckling pup (Kuo et al., 2006). Intestine-specific Ctrl-knockout mice accumulate copper in the intestine (Nose et al., 2006). The subcellular localization and

\footnotetext{
* Correspondence to: Dr. G.K. Andrews, Department of Biochemistry and Molecular Biology, Mail Stop 3030, University of Kansas Medical Center, 39th and Rainbow Blvd., Kansas City, KS 66160-7421. E-mail: gandrews@kumc.edu. NOTE ADDED IN PROOF

A recent report (Galy et al., 2008) demonstrated that mice lacking only intestinal IRP expression develop malabsorption and dehydration and die before weaning. Those studies also revealed that IRPs control the expression of DMT1 and ferroportin in the duodenum. (Galy B, Ferring-Appel D, Kaden S, Grone HJ, and Hentze MW. 2008. Iron regulatory proteins are essential for intestinal function and control key iron absorption molecules in the duodenum. Cell Metab 7: 79-85).
} 
abundance of CTR1 are cell-type specific (Klomp et al., 2002; Kuo et al., 2006). Copper is exported from enterocytes into the blood stream via the ATP7A P-type ATPase transporter which is localized to the basolateral membrane and secretory pathway (Hamza et al., 2003; Nyasae et al., 2007). The importance of ATP7A in copper homeostasis is revealed by the fact that copper export from enterocytes is impaired in patients with Menkes disease (MNK) and in mice with mutations in the Atp $7 a$ gene (mottled/brindled mouse), resulting in a severe copper deficiency phenotype (Mercer, 1998). Copper homeostasis is further regulated by the liver which sequesters copper absorbed from the diet (Lutsenko et al., 2007). Hepatocytes are important for copper loading into ceruloplasmin $(\mathrm{CP})$, a ferroxidase, which is the primary copperbinding protein in serum, and excess copper is excreted into the bile (Lutsenko et al., 2007; Shim and Harris, 2003). Both of these processes are regulated by ATP7B P-type ATPase transporter. Patients with Wilson's disease (WND) have mutations in Atp $7 b$ resulting in the hyperaccumulation of copper in the liver because of impaired excretion of copper into the bile and secretory pathway (where copper is loaded into CP).

Copper deficiency in neonatal mice leads to increase levels of CTR1 in several organs (Kuo et al., 2006) whereas highly elevated copper stimulates its rapid endocytosis and degradation (Petris et al., 2003). In the mammary gland, prolactin increases the abundance and plasma membrane localization of CTR1 and ATP7A (Kelleher and Lonnerdal, 2006a). Copper stimulates the trafficking of ATP7A and ATP7B proteins, which are localized to the transGolgi network (TGN) when copper concentrations are normal, and are trafficked to cytosolic vesicles as copper increases. ATP7A is further trafficked to the plasma membrane in response to extreme concentrations of copper whereas ATP7B apparently is not (Kim and Petris, 2007; Lutsenko et al., 2007).

Copper inside the cell is distributed to three major destinations: SOD1 in the cytosol, CCO in mitochondria, and cupric enzymes in the TGN (Prohaska and Gybina, 2004). Specific copper chaperones have essential functions in the distribution of intracellular copper (Fig 1, see GENERIC CELL). CCS, the copper chaperone for SOD delivers copper specifically to SOD1 and the copper chaperone ATOX1 interacts with ATP7A and ATP7B and delivers copper into the TGN. The assembly of CCO is a complex process that involves several copper chaperones (Cobine et al., 2006; Hamza and Gitlin, 2002; Horng et al., 2005; Sacconi et al., 2005). It is thought that COX17, and perhaps the structurally related COX19 and COX23/MTCP1 (Barros et al., 2004; Sacconi et al., 2005; Schoenfeld et al., 2005), transfer copper to the mitochondrial inner membrane. COX17 transfers copper to both COX11 and SCO1 which participate in the assembly of CCO (Cobine et al., 2006; Horng et al., 2005). Studies of Bedlington Terriers with copper toxicosis resembling WND lead to the identification of COMMD1 (MURR1) (Van de Sluis et al., 2002) which directly interacts with ATP7B and regulates its stability (de Bie et al., 2007; Tao et al., 2003). Regulation of the ubiquitin pathway may account for many functions of the COMMD protein family (Maine and Burstein, 2007). It was recently discovered that X-linked Inhibitor of Apoptosis (XIAP) regulates COMMD1 protein levels via its ubiquitin E3 ligase activity, and therefore functions as a modulator of copper homeostasis (Burstein et al., 2004). XIAP directly binds copper leading to a conformational change and causing decreased stability of the protein and loss of XIAP's caspase blocking activity (Mufti et al., 2007). This feedback regulation may be important for copper homeostasis.

\section{COPPER HOMEOSTASIS AND DEVELOPMENT}

Copper is required for normal development (Keen et al., 1998; Madsen and Gitlin, 2007) and dietary copper deficiency during embryonic development can be teratogenic and embryotoxic. Mouse embryos with swollen hind brains and offspring with severe neurological impairment and organogenesis defects in multiple tissues (severe connective tissue abnormalities, skeletal defects, lung abnormalities, etc.) are observed in offspring from copper deficient dams (Keen 
et al., 1998). The extent and timing of copper deficiency dictate the severity and tissuespecificity of the effects on the embryo, fetus, and newborn.

Mutations in genes that control copper homeostasis accentuate the multiple roles of copper during embryogenesis and early development (Table 1). This topic has been the subject of recent reviews (Madsen and Gitlin, 2007;Shim and Harris, 2003). CTR1 and Cox17 homozygous knock-out mice both die around E8.5-E10.5 suggesting that the acquisition of copper by the embryo becomes critical during gastrulation and mesoderm formation (Kuo et al., 2001; Lee et al., 2001;Takahashi et al., 2002). As discussed later, the acquisition of zinc and iron by the embryo also becomes essential at about this stage of mouse development. It is interesting to note, however, that CTR1 has recently been shown to play roles in coordinating morphogenesis and progenitor cell fate, and in regulating embryonic stem cell differentiation (Haremaki et al., 2007). In Xenopus laevis, CTR1 both promotes differentiation and inhibits the morphogenesis of mesoderm and neurectoderm, perhaps by activating the Ras-MAP kinase cascade (Haremaki et al., 2007). Similar concepts regarding roles of zinc in regulating signal transduction cascades have recently emerged (Beyersmann and Haase, 2001;Haase and Maret, 2005;Haase and Rink, 2007;Klein et al., 2002;Yamasaki et al., 2007).

Mutations in Atp7a in mottled/brindled mouse strains lead to three distinct phenotypes which reflect differences in copper transport and trafficking functions of the ATP7A protein (Kim and Petris, 2007). An early embryonic lethal phenotype of Atp $7 a(\mathrm{mo} 11 \mathrm{H})$ reflects a lack of copper delivery to the secretory pathway, whereas perinatal lethality of Atp7a (moMacular) reflects decreased copper delivery to the secretory pathway and constitutive localization to the plasma membrane (Kim and Petris, 2007). ATP7A plays a role in brain development. It is abundant in axons of the neonatal mouse brain but absent from adult axons (El Meskini $e t$ al., 2005), and in the mottled/brindled mouse ATP7A deficiency in Purkinje cells and olfactory sensory neurons is associated with impaired synaptogenesis and axonal targeting (El Meskini et al., 2007; Niciu et al., 2007). In Drosophila, the orthologous copper transporter DmATP7 is essential for early larval development and adult pigmentation (Norgate et al., 2006). In zebrafish, copper plays a key role in development of the notochord. Mutations in the orthologue of Atp7a (calamity) result in copper deficiency phenotypes, and Atp7a gene dosage determines the sensitivity to copper deficiency consistent with the concept that suboptimal copper can contribute to birth defects (Mendelsohn et al., 2006).

The functions of the newly identified COMMD1 and XIAP in copper homeostasis during development remain to be clarified, but current information suggests links between the control of apoptosis, hypoxia, copper homeostasis, and the ubiquitin pathway. Although Xiap knockout mice display no overt phenotype (Harlin et al., 2001), cells from these mice contain reduced copper levels and modestly elevated levels of COMMD1 (Burstein et al., 2004). In contrast, Commdl knockout embryos die on E9.5-E10.5, similar to the timing of lethality of Ctrl and Cox17 knockout embryos, as mentioned earlier (Van de Sluis et al., 2007), but Commd1 knockout embryos display heightened expression of hypoxia- inducible factor-1 (HIF-1) target genes, because of increased stability of HIF- 1 and an absence of placental vascularization (Van de Sluis et al., 2007). The role of copper homeostasis in these processes remains obscure.

The proper transfer of copper from the mother to the developing embryo and neonate is also of critical importance. Toxic milk mice and mice with targeted mutations in Atp $7 b$ produce copper deficient breast milk, leading to neurological abnormalities, growth retardation, and death of the suckling pup (Buiakova et al., 1999). Similarly, the conditional knockout of Ctrl in the neonatal intestine is lethal before weaning, but this phenotype can be ameliorated by copper administration (Nose et al., 2006). 
The copper chaperone ATOX1 plays a critical role in perinatal copper homeostasis (Hamza et al., 2001), and about half (45\%) of homozygous Atoxl knockout offspring die before weaning while surviving pups fail to grow, have loose skin, hypopigmentation, and seizures. Maternal Atoxl deficiency exacerbates the severity of the copper deficiency phenotype of homozygous offspring (Hamza et al., 2001). Atoxl knockout cells accumulate excess intracellular copper because of impaired efflux, and ATOX1 plays an essential role in the coppermediated trafficking of ATP7A (Hamza et al., 2003).

Mutations in Scol/Sco2 copper chaperone genes have been documented in humans. Mutations in Sco 2 may cause fatal infantile cardioencephalomyopathy and CCO deficiency (Papadopoulou et al., 1999), whereas mutations in Scol are associated with neonatal-onset liver failure and encephalopathy (Valnot et al., 2000). It is interesting to note that these phenotypes differ from patients with other mutations that affect $\mathrm{CCO}$ assembly. This suggests that SCO1 and SCO2 may have functions in addition to CCO assembly.

Almost all of the copper in blood is bound to CP but mutations in the $c p$ gene are not associated with defective copper metabolism, but rather have been associated with defective iron metabolism. In humans CP deficiency has been associated with late-onset retinal and basal ganglia degeneration (Harris et al., 1995) and increased iron accumulation in the liver and other tissues. This role for $\mathrm{CP}$ in iron metabolism reflects its function as a copper-containing ferroxidase, and mice with $\mathrm{CP}$ deficiency have impaired intestinal uptake of iron (Cherukuri et al., 2005).

\section{REGULATION OF ZINC HOMEOSTASIS}

Zinc serves structural and/or catalytic roles in hundreds of peptides (Berg and Shi, 1996; Krishna et al., 2003; Ravasi et al., 2003; Vallee and Auld, 1990) and is the second most abundant essential metal. Therefore, when zinc is deficient numerous cellular processes are affected. Zinc deficiency during development is highly teratogenic and embryotoxic, and the outcomes are highly variable depending on the extent and timing of the zinc deficiency. Zinc is also toxic when in excess. Therefore, the maintenance of zinc homeostasis is critical and multiple genes have evolved to modulate the storage (4 Metallothionein genes in mice), efflux (10 Znt genes), and uptake (14 Zip genes) of this metal in response to zinc availability (see Fig. 2). In addition, recent studies suggest the possibility that zinc may be stored in and released from intracellular vesicular compartments (Devirgiliis et al., 2004; Yamasaki et al., 2007). The zinc transporters of higher eukaryotes are often expressed in a tissue-specific manner and in specific cellular localizations. In addition, they can display specific changes in cellular localization and stability in response to zinc deficiency or excess (Cousins et al., 2006; Eide, 2006; Kambe et al., 2004). The diverse roles of these molecules in zinc homeostasis are only beginning to be understood and much remains to be determined.

When zinc is replete in the diet, it is absorbed from the gut by enterocytes in the small intestine, and excess zinc is released through the pancreas and small intestine, as well as in small amounts from the kidney (Hambidge and Krebs, 2001; King et al., 2000; McClain, 1990). However, under zinc-deficient conditions, zinc absorption by the small intestine increases, and release from the pancreas and small intestine decreases (Hambidge and Krebs, 2001). In the embryonic environment of the mouse, the visceral endoderm plays an important role in zinc homeostasis during peri-implantation development (Dufner-Beattie et al., 2007). How animals and cells adapt to zinc status and the roles of these zinc transporters (uptake and efflux) in the adaptive process are active areas of investigation. 


\section{METALLOTHIONEINS AND MTF-1 IN DEVELOPMENT}

A portion of the total cellular zinc pool $(\sim 5-15 \%)$ can be bound by the cysteine-rich metallothioneins (MT) (Coyle et al., 2002). In the mouse, there are four MT family members, and in humans there are eleven (Kagi, 1991). Mt genes (Mt-I and Mt-II in mice) are zincregulated by the transcription factor MTF-1 (Laity and Andrews, 2007); in the presence of high zinc their transcription rate is increased (see Fig. 2). In contrast, under low zinc conditions, MT levels decrease because of a lower transcription rate and protein destabilization (Andrews, 1990). Although $M t$ genes are nonessential in mice, MTs appear to function as a "zinc buffer" that can provide a labile pool of zinc for use by other proteins when zinc is limiting (Krezel and Maret, 2007; Maret and Krezel, 2007). Deletion of Mt-I and Mt-II genes sensitizes mice to the teratogenic effects of zinc deficiency during pregnancy (Andrews and Geiser, 1999), whereas overexpression of $M t-I$ dramatically protects mice from these effects (Dalton et al., 1996) (Table 2).

The zinc-finger transcription factor MTF-1 regulates basal and metal-induced expression of mammalian $M t$ genes (Lichtlen and Schaffner, 2001). Deletion of the $M t f-1$ gene in mice is lethal at E14 because of degeneration of the liver (Günes et al., 1998). This appears to be a cell-autonomous effect (Wang et al., 2004), but its relationship with zinc metabolism in the embryo is unclear. MTF-1 is also essential for basal expression and zinc regulation of $M t$ genes in the visceral endoderm of the mouse embryo (Andrews et al., 2001), and this tissue appears to play a key role in the acquisition of essential metals during development, as is discussed later. Interestingly, MTF-1 regulates zinc-responsiveness of the Znt1 (a major zinc efflux transporter) gene (Langmade et al., 2000) and represses expression of the Zip10 gene, a member of the zinc uptake transporter family whose function during development is unknown (Wimmer et al., 2005). These findings suggest that mammalian MTF-1 plays an important role in zinc homeostasis.

\section{ZnT FAMILY ZINC TRANSPORTERS (SIc30a) IN DEVELOPMENT}

Two superfamilies of mammalian zinc transporters have been identified that belong to the solute carrier (Slc)30a and the Slc39a families (Guerinot, 2000; Palmiter and Huang, 2004; Taylor and Nicholson, 2003). Slc30a members, named ZnTs, function in zinc efflux and compartmentalization and are cation diffusion proteins (Palmiter and Huang, 2004). There are 10 members of this family in mammals and several are known to have important functions during development. Only those are discussed herein (Seve et al., 2004) (Table 2). Targeted deletion of Zntl results in early embryonic lethality in homozygous knockout mice (Andrews et al., 2004). High levels of Znt1 mRNA are found in the maternal deciduum and in the visceral yolk sac surrounding the embryo, which suggests that this protein is involved in the transfer of maternal zinc into the uterine and embryonic environments (Andrews et al., 2004). ZnT1 is a ubiquitous zinc efflux transporter that can protect cells in vitro from zinc toxicity (Palmiter, 2004). The naturally occurring lethal milk mouse carries a nonsense mutation in the Znt4 gene (Huang and Gitschier, 1997). These mice produce zinc-deficient milk which, in turn, causes a lethal zinc deficiency in the nursing pups. A recent study found heterozygous mutations in the human Znt2 gene in women with low zinc concentrations in milk leading to transient zinc deficiency and dermatitis in the nursing child (Chowanadisai et al., 2006). Homozygous deletion of Znt5 results in poor growth, osteopenia, low body fat, muscle weakness, and malespecific cardiac death (Inoue et al., 2002). Complexes containing ZnT5 and 6, as well as complexes containing homo-oligomers of ZnT7 function to transport zinc into the secretory pathway which activates zinc-requiring enzymes such as alkaline phosphatase (Suzuki et al., $2005 \mathrm{a}, \mathrm{b})$. Our understanding of this family of zinc transporters has advanced significantly in the past few years. In contrast, we know much less about zinc uptake transporters. 


\section{ZIP FAMILY ZINC TRANSPORTERS (SIc39a) IN DEVELOPMENT}

Members of the Slc39a family, named ZIPs, function in the uptake of zinc and other metals (Eng et al., 1998; Guerinot, 2000; Taylor and Nicholson, 2003), and members of this family are found in all eukaryotes. In mice and humans there are 14 members of the ZIP family. The Slc39a superfamily can be subdivided into four subfamilies based on structural homology (Taylor and Nicholson, 2003). In mammals, most ZIP proteins fall into one of two subfamilies named subfamily II (3 members) and LIV-1 (9 members).

Members of subfamily II (ZIPs1-3) were the first to be described in mammals. They are well conserved, can function to transport zinc in transfection studies, and are actively expressed in a highly cell-specific manner in mice (Dufner-Beattie et al., 2003a, 2005, 2006; Gaither and Eide, 2001; Huang et al., 2006; Peters et al., 2007). Targeted deletion of mouse ZIP1, 2, or 3 genes revealed that none of these genes is essential (Dufner-Beattie et al., 2006; Peters et al., 2007) and deletion of the entire subfamily also does not cause an obvious phenotype (Andrews et al., manuscript in preparation). However, subfamily II knockout mice are dramatically more sensitive to the teratogenic effects of dietary zinc deficiency during pregnancy (Dufner-Beattie et al., 2005, 2006). The zinc deficient knockout embryos are severely growth retarded and have obvious cranio-facial abnormalities and limb defects. ZIPs1, 2, and 3 appear to function specifically during adaptation to zinc deficiency consistent with the finding that these proteins are recruited to the surface in zinc deficient cells (Wang et al., 2004).

Several members of the LIV-1 subfamily have interesting roles in early development. In humans, mutations in the Zip4 gene cause the rare and fatal genetic disorder acrodermatitis enteropathica (Kury et al., 2002; Wang et al., 2002) which reflects an impaired ability of the intestine to absorb dietary zinc. The symptoms of this disease often appear after weaning in humans but can be ameliorated by dietary zinc supplementation (Maverakis et al., 2007). In contrast, the mouse Zip4 gene is essential during early embryonic development (E7.5-E9) and the homozygous knockout embryos fail to undergo morphogenesis (Dufner-Beattie et al., 2007). Although expression of Zip4 can be detected in the preimplantation mouse embryo, it is actively expressed only in the visceral endoderm on E7.5 when the embryo is at the egg cylinder stage of development.

Interestingly, Zip4 heterozygosity is teratogenic and embryotoxic in mice. These effects are highly pleiotropic and include growth retardation, exencephalia, and cranio-facial abnormalities in midgestation embryos, as well as hydrocephalia, anopia (loss of eyes), heart and skeletal defects in a significant percentage of the offspring (Dufner-Beattie et al., 2007). These abnormalities are largely prevented by supplementation of dietary zinc. Later during pregnancy (E14), Zip4 gene expression in the visceral endoderm is regulated by zinc availability (Dufner-Beattie et al., 2003b). During zinc deficiency, Zip4 mRNA and protein stability are increased and ZIP4 is trafficked to the apical membrane. Repletion of zinc causes the rapid internalization and destabilization of ZIP4 in the visceral endoderm (Weaver et al., 2007). This pattern of regulation mimics that seen in the adult intestine where ZIP4 serves an essential function in the uptake of dietary zinc.

The functions of other mammalian ZIP family members in development remain to be explored, but it is interesting to note that the fear-of-intimacy gene in Drosophila encodes a LIV-1-like protein that can function as a zinc transporter and that is essential during early development of the fly (Mathews et al., 2005; Moore et al., 1998). This gene controls germ cell migration and gonad formation which suggests a key role for zinc in these processes. Similarly, morpholino knockdown of zebrafish $z$ Liv-1 revealed a function in epithelial-mesenchymal transition in the gastrula (Yamashita et al., 2004). zLiv-1 is a downstream target of STAT3, and is essential for the nuclear localization of the zinc-finger protein Snail, which regulates epithelial- 
mesenchymal transition. Remarkably, human ZIP6, the founding member of the LIV-1 family, plays a role in cell invasion by targeting the ERK1/2-Snail/Slug pathway (Zhao et al., 2007). In addition, ZIP10 has recently been shown to play a role in breast cancer invasive behavior (Kagara et al., 2007), and aberrant Zip4 expression in pancreatic ductal carcinoma has been reported to correlate with metastatic potential (Li et al., 2007). Zip4 expression in the pancreas is normally restricted to pancreatic $\beta$-cells (Dufner-Beattie et al., 2004). Thus, several members of the LIV-1 family may have fundamental functions in regulating cell migration and differentiation during early development.

\section{ZINC SIGNALING AND ITS POTENTIAL ROLE IN DEVELOPMENT}

Zinc has been suggested to function as an intracellular second messenger as well as extracellular signaling molecule. These effects may, in turn, impact development of the embryo, although this concept has not yet been supported by direct evidence (Beyersmann and Haase, 2001; Hansson, 1996; Kim et al., 2000; Yamasaki et al., 2007). Zinc influences signal transduction cascades in a cell-type and zinc concentration-dependent manner. For example, low micromolar concentrations of zinc inhibit hormone- or forskolin-stimulated cAMP production in neuroblastoma cells, perhaps by directly interacting with adenylate cyclase and altering the $V_{\max }$ of the enzyme (Klein et al., 2002). Similarly, zinc treatment can inhibit cyclic nucleotide phosphodiesterase activity and expression in monocytes, resulting in increased levels of cGMP, activation of protein kinase A, and subsequent inhibition of Raf-1. This leads to altered NF$\kappa \mathrm{B}$ signaling and suppression of TNF- $\alpha$ production (vonBulow et al., 2007). Zinc also has insulinomimetic effects and apparently small increases in intracellular zinc can inhibit protein tyrosine phosphatase 1B activity in insulin and insulin-like growth factor signaling leading to increased phosphorylation of the receptor (Haase and Maret, 2005; Samet et al., 2003). Zinc also influences the EGF pathway and the NMDA receptor (cited in Samet et al., 2003). In $C$. elegans, $C d f-1$, which encodes a protein functionally similar to vertebrate ZnT-1, was identified as a positive regulator of the Ras pathway, by promoting zinc efflux and relieving repression of Ras-mediated signaling (Bruinsma et al., 2002).

The release of intracellular zinc leads to the activation of 12-lipoxygenase and p38 mitogenactivated protein kinase (MAPK), which contributes to the toxicity of zinc in neurons and oligodendrocytes (Zhang et al., 2007). These authors also comment that extracellular signalregulated kinase (ERK1/2) activation, caused by glutathione depletion during oxidative stress, is mediated by the intracellular release of zinc in HT22 cells (Zhang et al., 2007). A recent study of mast cells revealed that crosslinking IgE receptors induces the release of free zinc from the perinuclear area and ER, an effect dependent on calcium influx and MAPK activation, suggesting that zinc may function as a novel intracellular second messenger (Yamasaki et al., 2007). Given the roles of extracellular and intracellular zinc in regulating cell signaling, it seems likely that altering zinc homeostasis at a critical time in early development would have dramatic, pleiotropic effects on morphogenesis of the embryo.

\section{REGULATION OF IRON HOMEOSTASIS}

Iron is the most abundant transition metal and is utilized in both Fe-S cluster containing proteins and proteins that contain porphyrin conjugates, primarily heme. Iron deficiency is the most common cause of anemia and iron overload results in toxicity because of increased free radical formation. In the past decade significant advances have been made in our understanding of iron homeostasis and this subject has been recently reviewed in much greater detail than can be presented herein (Andrews and Schmidt, 2007; DeDomenico et al., 2008). A brief overview is presented later (see Fig. 3). 
Iron is regulated primarily at the level of absorption (Andrews and Schmidt, 2007;

DeDomenico et al., 2008) (see Fig. 3) and is lost from the body by bleeding and sloughing of the gut epithelium. Heme-conjugated iron is a major dietary source of iron, but a high-affinity heme transporter has not been identified (Qiu et al., 2006). Nonheme iron in the gut is reduced to $\mathrm{Fe}^{2+}$ by a ferric reductase(s) (Miret et al., 2003) and transported into the enterocyte by DMT1 (Slc11a2) (DeDomenico et al., 2008). Iron is transported out of the enterocyte into the circulation by ferroportin (Slc40a1) (Donovan et al., 2005) where it is oxidized to $\mathrm{Fe}^{3+}$ by hephaestin and perhaps CP (Miret et al., 2003). DMT1 is not essential for iron uptake in the fetus (Gunshin et al., 2005). In fact, alternate and as yet unidentified iron uptake mechanisms exist in hepatocytes, placenta, and most other cells. Ferroportin, in contrast, plays a key role in iron export from the visceral endoderm of the yolk sac (Donovan et al., 2005). In the circulation, transferrin binds $\mathrm{Fe}^{3+}$ and transports it throughout the body.

Transferrin receptor-mediated endocytosis is the major path by which all cells take up iron (DeDomenico et al., 2008). Receptor bound transferrin undergoes endocytosis, $\mathrm{Fe}^{3+}$ is released from transferrin in the acidified endosome, and apo-transferrin and its receptor are recycled back to circulation and plasma membrane, respectively (Fig. 3, see GENERIC CELL).

Transferrin receptor-1 is a high-affinity, ubiquitously expressed receptor; in contrast transferrin receptor-2 is expressed predominately in the liver and its function is not known (Wallace $e t$ al., 2008). The released $\mathrm{Fe}^{3+}$ is reduced to $\mathrm{Fe}^{2+}$ by a member of the STEAP metalloreductase family (STEAP3 in the erythroblast) and transported out of the endosome by DMT1 (Ohgami et al., 2006). In all nonerythroid cells, any free iron is chelated by ferritin. Iron is transported into mitochondria by mitoferrin (Slc25a37) (Shaw et al., 2006) where it is loaded into Fe-S clusters in a frataxin-dependent process and used for heme synthesis in red blood cells (Muhlenhoff et al., 2002). Mitochondria also export a substrate essential for cytosolic Fe-S cluster assembly via the ATP-binding cassette transporter ABCB7 complex (Burke and Ardehali, 2007; Lill et al., 2006). The heme in red blood cells represents the largest pool of iron in the body. Heme iron is recycled by macrophages of the reticuloendothelial system which phagocytose aged red blood cells (see Fig. 3). Iron is transported out of the lysosome by NRAMP1 (Slc11a1) (Lam-Yuk-Tseung et al., 2006) and ultimately released from the macrophage by ferroportin as $\mathrm{Fe}^{2+}$ which is then oxidized by $\mathrm{CP}$ and bound again by transferrin (Andrews and Schmidt, 2007). Macrophages play an essential role in iron homeostasis.

Iron homeostasis is tightly controlled by several posttranscriptional mechanisms. In brief, the iron-regulatory proteins (IRP1 and IRP2) function as iron sensors that regulate iron metabolism genes as well as some genes with no direct link to iron metabolism. IRPs regulate the stability of transferrin receptor-1 mRNA and the translation of ferritin mRNA by binding to stem-loop structures termed iron-responsive elements (IRE) in the UTRs of these mRNAs. Transferrin receptor-2 mRNA lacks IREs and is not iron-regulated (Fleming et al., 2000). When iron is limiting, IRPs bind to the 5' UTR of ferritin mRNA and block its translation and bind to the 3' UTR of transferrin receptor-1 mRNA which is stabilized (DeDomenico et al., 2008). DMT1 and ferroportin mRNAs also contain IREs that are thought to be regulated by IRPs.

Ferroportin transporter activity is downregulated by the binding of the peptide hormone hepcidin which causes phosphorylation of ferroportin and its subsequent internalization, ubiquitination, and degradation (DeDomenico et al., 2008; Ganz, 2007). Hepcidin therefore inhibits dietary iron absorption and the efflux of recycled iron from macrophages. Hepcidin is secreted by hepatocytes in response to several different stimuli (DeDomenico et al., 2007b). Hypoxia resulting from anemia or other causes, inflammatory cytokines, and iron all regulate hepcidin secretion. Not all of the mechanisms of hepcidin (hamp) gene regulation are understood, but transcription of hamp is induced by Stat 3 in response to Il-6 (Wrighting and Andrews, 2006) and by bone morphogenic protein/Smad4 signaling in response to membranebound hemojuvelin (Babitt et al., 2006, 2007; Silvestri et al., 2008). Hemojuvelin acts as a 
BMP coreceptor which facilitates BMP receptor activation (Babitt et al., 2006). The transcription factor HIF-1 $\alpha$ represses hamp gene expression in response to hypoxia (Peyssonnaux et al., 2007). Regulation of ferroportin is important for proper maintenance of iron homeostasis.

\section{IRON HOMEOSTASIS AND DEVELOPMENT}

Hypochromic, microcytic anemias resulting from defects in iron metabolism genes leading to impaired development of red blood cells have provided insight into the mechanisms of homeostasis of this essential metal. Several rodent strains (Table 3) have been described that have defective erythropoiesis such as hypotransferrinemic $\left(T f^{h p x}\right)$ mice, sex-linked anemia $\left(\mathrm{Heph}^{\text {sla }}\right.$ ) mice, $\mathrm{nm} 1054$ (Steap3) mice, the Belgrade rat (Slc1la2 $\left.{ }^{b}\right)$, and microcytic anemia $\left(\right.$ Slc1la2 ${ }^{m k}$ ) mice (Andrews, 2000;Ohgami et al., 2005; Touret et al., 2004). Similarly, Dmt1 (Slc11a2) knockout mice (Gunshin et al., 2005), the zebrafish mutants Chianti (Tfrla) (Wingert et al., 2004), Chardonnay (Dmt1) (Donovan et al., 2002), and Frascati (mitoferrin: Mfrn) (Shaw et al., 2006) show erythoid maturation arrest. The zebrafish mutant weisshergst exhibits a defect in hemoglobin accumulation, because of mutations in the Ferroportin (Fpn) gene, which is also eventually lethal (Donovan et al., 2000).

Mutations in iron metabolism genes can profoundly affect embryonic, fetal, and perinatal development. Mice with targeted deletions of the $A b c b 7$ gene, which is essential for cytosolic Fe-S cluster assembly, die soon after implantation because of a defect in extraembryonic tissues, but this gene is critical for the development of many cell types and is mutated in Xlinked sideroblastic anemia with ataxia (Pondarre et al., 2006). Frataxin (FXN) functions as a chaperone for mitochondrial (and extramitochondrial) Fe-S cluster biogenesis (Martelli $e t$ al., 2007; Muhlenhoff et al., 2002). Knockout of the mouse Fxn gene revealed that it is essential, and homozygous embryos also die a few days after implantation (Cossee et al., 2000). The mechanism of lethality may not be associated with iron accumulation as is seen in Friedreich's ataxia. It is interesting to note that the Fxn gene in Arabidopsis thaliana is essential at the globular stage of early development when the three major tissue types emerge (Vazzola et al., 2007). The flatiron (ffe) mutation in mice is due to a hypomorphic Fpn mutation that exerts a dominant negative function in heterozygous mice leading to iron loading in the liver, high serum ferritin, and low transferrin iron saturation, whereas homozygous ffe embryos die at midgestation and have severe anemia (Zohn et al., 2007). In contrast, Fpnknockout mice revealed that this iron export protein is essential for development of the early ( E7.5) embryo (Table 3) (Donovan et al., 2005). Ferroportin is localized to the basolateral membrane of the visceral endoderm at this stage of development and conditional knockout of $F p n$ in the visceral endoderm confirms its importance in those cells. Mice heterozygous for Fpn exhibit smaller cell volume and lower intracellular hemoglobin in both developing reticulocytes and mature erythrocytes in adults (Donovan et al., 2005).

Perturbations of intracellular iron storage and distribution can also negatively impact development. Knockout of the mouse $\mathrm{H}$-ferritin (Fthl) gene is early embryonic lethal when homozygous (Ferreira et al., 2000) and L-ferritin cannot complement the loss of function of Fth1. This suggests that these isoforms of ferritin have unique functions and that the ability to store/chelate/distribute iron is essential during early development. The expression pattern of Fthl suggests a prominent role in development of the heart (Ferreira et al., 2000). Fthl expression in the E9.5 mouse embryo is restricted to heart and CNS but later becomes more ubiquitous (Ferreira et al., 2000).

IRP1 and IRP2 regulate iron metabolism genes at the posttranscriptional level. Neither alone is essential for development. IRPI knockout mice misregulate iron metabolism in the kidney and brown fat, whereas IRP2 knockout mice misregulate iron homeostasis in all tissues and 
develop adult-onset neurodegenerative disease (Smith et al., 2004). Mice with a single allele of IRPI and no functional IRP 2 genes develop a more severe form of neurodegeneration (Smith et al., 2004), whereas a complete loss of both IPRI and IRP2 genes is embryonic lethal (Smith et al., 2006). These double-knockout blastocysts were discolored and morphologically abnormal perhaps because of the overexpression of ferritin and they did not survive past E6.5 in utero (Smith et al., 2006).

Homozygous knockout of transferrin receptor-1 (TfRI) in mice revealed its essential roles in erythropoiesis and in development of the central nervous system (Levy et al., 1999).

Homozygous $T f r l$ knockout mice die in utero and are severely anemic with increased apoptosis in the neuroepithelium. Haploin sufficiency of $T f r l$ is associated with microcytic anemia and reduced iron stores. In contrast, $T f r 2$ knockout mice are viable but conditional knockout of this gene in the adult liver leads to iron overload (Wallace et al., 2004, 2007) similar to type 3 hemochromatosis in humans, suggesting a role for TFR2 as an iron-bound transferrin sensor (Johnson and Enns, 2004; Robb and Wessling-Resnick, 2004; Wallace et al., in press).

\section{ESSENTIAL METAL INTERACTIONS}

Although most of the above discussion has dealt with these essential metals individually, it should be noted that there are significant interactions between essential metals and the status of one metal can affect that of another. For example, excess zinc induces copper deficiency which may lead to diminished intestinal absorption of iron (Cherukuri et al., 2005) and decreased activity of $\mathrm{CP}$, the copper containing ferroxidase, which in turn may destabilize ferroportin (DeDomenico et al., 2007a). Marginal zinc deficiency in pregnant rats leads to increased maternal $\mathrm{CP}$ and increased copper in the milk, perhaps by increasing the expression of $C t r l, A t p 7 a$, and Atp $7 b$ genes in the mammary gland, which in turn can cause signs of copper toxicity in the nursing pups (Kelleher and Lonnerdal, 2003). Analyses of all of the essential metal ions in the liver and embryos of Zip2- knockout mice revealed unique alterations in iron but not zinc levels (Peters et al., 2007). Zinc deficiency has been shown to cause an increase in iron in the liver, whereas zinc excess competes for iron uptake in the gut (Hurley et al., 1983; Kelleher and Lonnerdal, 2006b; Kordas and Stoltzfus, 2004; Yamaji et al., 2001), perhaps by altering the activity of iron transport in the intestine. Zip2-knockout mice fail to accumulate iron in the liver during zinc deficiency (Peters et al., 2007), but the mechanisms underlying this effect are unknown.

Zinc and calcium metabolism are also interconnected (Maret, 2001). A functional link has been proposed between L-type calcium channels and the zinc efflux transporter ZnT1 (Ohana et al., 2006; Segal et al., 2004), and extracellular zinc can trigger the release of calcium from intracellular pools in HT29 cells (Hershfinkel et al., 2001) and inhibit calcium influx in several cultured cell lines (Gore et al., 2004). A dramatic increase in calcium occurs in embryos from zinc-deficient Zip2-knockout mice (Peters et al., 2007). However, there is no evidence that any ZIP family member can transport calcium suggesting an indirect role of ZIP2 in calcium metabolism.

\section{Acknowledgements}

T.K. was supported, in part, by a fellowship from the Kanae Foundation for the Promotion of Medical Science.

Contract grant sponsor: NIH; Contract grant numbers: DK063975, DK059369.

\section{LITERATURE CITED}

Andrews GK. Regulation of metallothionein gene expression. Prog Food Nutr Sci 1990;14:193-258. [PubMed: 2293243] 
Andrews GK, Geiser J. Expression of metallothionein-I and -II genes provides a reproductive advantage during maternal dietary zinc deficiency. J Nutr 1999;129:1643-1648. [PubMed: 10460198]

Andrews GK, Lee DK, Ravindra R, Lichtlen P, Sirito M, Sawadogo M, Schaffner W. The transcription factors MTF-1 and USF1 cooperate to regulate mouse metallothionein-I expression in response to the essential metal zinc in visceral endoderm cells during early development. EMBO J 2001;20:11141122. [PubMed: 11230134]

Andrews GK, Wang H, Dey SK, Palmiter RD. The mouse zinc transporter 1 gene provides an essential function during early embryonic development. Genesis 2004;40:74-81. [PubMed: 15452870]

Andrews NC. Iron homeostasis: Insights from genetics and animal models. Nat Rev Genet 2000;1:208217. [PubMed: 11252750]

Andrews NC, Schmidt PJ. Iron homeostasis. Annu Rev Physiol 2007;69:69-85. [PubMed: 17014365]

Babitt JL, Huang FW, Wrighting DM, Xia Y, Sidis Y, Samad TA, Campagna JA, Chung RT, Schneyer AL, Woolf CJ, Andrews NC, Lin HY. Bone morphogenetic protein signaling by hemojuvelin regulates hepcidin expression. Nat Genet 2006;38:531-539. [PubMed: 16604073]

Babitt JL, Huang FW, Xia Y, Sidis Y, Andrews NC, Lin HY. Modulation of bone morphogenetic protein signaling in vivo regulates systemic iron balance. J Clin Invest 2007;117:1933-1939. [PubMed: 17607365]

Barros MH, Johnson A, Tzagoloff A. COX23, a homologue of COX17, is required for cytochrome oxidase assembly. J Biol Chem 2004;279:31943-31947. [PubMed: 15145942]

Berg JM, Shi YG. The galvanization of biology: A growing appreciation for the roles of zinc. Science 1996;271:1081-1085. [PubMed: 8599083]

Beyersmann D, Haase H. Functions of zinc in signaling, proliferation and differentiation of mammalian cells. Biometals 2001;14:331- 341. [PubMed: 11831463]

Bruinsma JJ, Jirakulaporn T, Muslin AJ, Kornfeld K. Zinc ions and cation diffusion facilitator proteins regulate Ras-mediated signaling. Dev Cell 2002;2:567-578. [PubMed: 12015965]

Buiakova OI, Xu J, Lutsenko S, Zeitlin S, Das K, Das S, Ross BM, Mekios C, Scheinberg IH, Gilliam TC. Null mutation of the murine $A T P 7 B$ (Wilson disease) gene results in intracellular copper accumulation and late-onset hepatic nodular transformation. Hum Mol Genet 1999;8:1665-1671. [PubMed: 10441329]

Burke MA, Ardehali H. Mitochondrial ATP-binding cassette proteins. Transl Res 2007;150:73-80. [PubMed: 17656326]

Burstein E, Ganesh L, Dick RD, Van de Sluis B, Wilkinson JC, Klomp LWJ, Wijmenga C, Brewer GJ, Nabel GJ, Duckett CS. A novel role for XIAP in copper homeostasis through regulation of MURR1. EMBO J 2004;23:244-254. [PubMed: 14685266]

Cherukuri S, Potla R, Sarkar J, Nurko S, Harris ZL, Fox PL. Unexpected role of ceruloplasmin in intestinal iron absorption. Cell Metab 2005;2:309-319. [PubMed: 16271531]

Chowanadisai W, Lonnerdal B, Kelleher SL. Identification of a mutation in SLC30A2 (ZnT-2) in women with low milk zinc concentration that results in transient neonatal zinc deficiency. J Biol Chem 2006;281:39699-39707. [PubMed: 17065149]

Cobine PA, Pierrel F, Winge DR. Copper trafficking to the mitochondrion and assembly of copper metalloenzymes. Biochim Biophys Acta 2006;1763:759-772. [PubMed: 16631971]

Cossee M, Puccio H, Gansmuller A, Koutnikova H, Dierich A, LeMeur M, Fischbeck K, Dolle P, Koenig M. Inactivation of the Friedreich ataxia mouse gene leads to early embryonic lethality without iron accumulation. Hum Mol Genet 2000;9:1219-1226. [PubMed: 10767347]

Cousins RJ, Liuzzi JP, Lichten LA. Mammalian zinc transport, trafficking, and signals. J Biol Chem 2006;281:24085-24089. [PubMed: 16793761]

Coyle P, Philcox JC, Carey LC, Rofe AM. Metallothionein: The multipurpose protein. Cell Mol Life Sci 2002;59:627-647. [PubMed: 12022471]

Dalton TP, Fu K, Palmiter RD, Andrews GK. Transgenic mice that over-express metallothionein-I resist dietary zinc deficiency. J Nutr 1996;126:825-833. [PubMed: 8613884]

de Bie P, van de SB, Burstein E, van de Berghe PV, Muller P, Berger R, Gitlin JD, Wijmenga C, Klomp LW. Distinct Wilson's disease mutations in ATP7B are associated with enhanced binding to COMMD1 and reduced stability of ATP7B. Gastroenterology 2007;133:1316-1326. [PubMed: 17919502] 
DeDomenico I, McVey WD, Kaplan J. Regulation of iron acquisition and storage: Consequences for iron-linked disorders. Nat Rev Mol Cell Biol 2008;7:72-81.

DeDomenico I, Ward DM, di Patti MC, Jeong SY, David S, Musci G, Kaplan J. Ferroxidase activity is required for the stability of cell surface ferroportin in cells expressing GPI-ceruloplasmin. EMBO J 2007a;26:2823-2831.

DeDomenico I, Ward DM, Kaplan J. Hepcidin regulation: Ironing out the details. J Clin Invest 2007b; 117:1755-1758.

Devirgiliis C, Murgia C, Danscher G, Perozzi G. Exchangeable zinc ions transiently accumulate in a vesicular compartment in the yeast Saccharomyces cerevisiae. Biochem Biophys Res Commun 2004;323:58-64. [PubMed: 15351701]

Donovan A, Brownlie A, Dorschner MO, Zhou Y, Pratt SJ, Paw BH, Phillips RB, Thisse C, Thisse B, Zon LI. The zebrafish mutant gene chardonnay (cdy) encodes divalent metal transporter 1 (DMT1). Blood 2002;100:4655-4659. [PubMed: 12393445]

Donovan A, Brownlie A, Zhou Y, Shepard J, Pratt SJ, Moynihan J, Paw BH, Drejer A, Barut B, Zapata A, Law TC, Brugnara C, Lux SE, Pinkus GS, Pinkus JL, Kingsley PD, Palis J, Fleming MD, Andrews NC, Zon LI. Positional cloning of zebrafish ferroportin1 identifies a conserved vertebrate iron exporter. Nature 2000;403:776-781. [PubMed: 10693807]

Donovan A, Lima CA, Pinkus JL, Pinkus GS, Zon LI, Robine S, Andrews NC. The iron exporter ferroportin/Slc40a1 is essential for iron homeostasis. Cell Metab 2005;1:191-200. [PubMed: 16054062]

Dufner-Beattie J, Huang ZL, Geiser J, Xu W, Andrews GK. Generation and characterization of mice lacking the zinc uptake transporter ZIP3. Mol Cell Biol 2005;25:5607-5615. [PubMed: 15964816]

Dufner-Beattie J, Huang ZL, Geiser J, Xu W, Andrews GK. Mouse ZIP1 and ZIP3 genes together are essential for adaptation to dietary zinc deficiency during pregnancy. Genesis 2006;44:239-251. [PubMed: 16652366]

Dufner-Beattie J, Kuo YM, Gitschier J, Andrews GK. The adaptive response to dietary zinc in mice involves the differential cellular localization and zinc-regulation of the zinc transporters ZIP4 and ZIP5. J Biol Chem 2004;279:49082-49090. [PubMed: 15358787]

Dufner-Beattie J, Langmade SJ, Wang F, Eide D, Andrews GK. Structure, function, and regulation of a subfamily of mouse zinc transporter genes. J Biol Chem 2003a;278:50142-50150. [PubMed: 14525987]

Dufner-Beattie J, Wang F, Kuo YM, Gitschier J, Eide D, Andrews GK. The acrodermatitis enteropathica gene ZIP4 encodes a tissue- specific, zinc-regulated zinc transporter in mice. J Biol Chem 2003b; 278:33474-33481. [PubMed: 12801924]

Dufner-Beattie J, Weaver BP, Geiser J, Bilgen M, Larson M, Xu W, Andrews GK. The mouse acrodermatitis gene Slc39a4 (ZIP4) is essential for development and heterozygosity causes hypersensitivity to zinc deficiency. Hum Mol Genet 2007;16:1391-1399. [PubMed: 17483098]

Eide DJ. Zinc transporters and the cellular trafficking of zinc. Biochim Biophys Acta 2006;1763:711722. [PubMed: 16675045]

El Meskini R, Cline LB, Eipper BA, Ronnett GV. The developmentally regulated expression of menkes protein ATP7A suggests a role in axon extension and synaptogenesis. Dev Neurosci 2005;27:333348. [PubMed: 16137991]

El Meskini R, Crabtree KL, Cline LB, Mains RE, Eipper BA, Ronnett GV. ATP7A (Menkes protein) functions in axonal targeting and synaptogenesis. Mol Cell Neurosci 2007;34:409-421. [PubMed: 17215139]

Eng BH, Guerinot ML, Eide D, Saier MH Jr. Sequence analyses and phylogenetic characterization of the ZIP family of metal ion transport proteins. J Membr Biol 1998;166:1-7. [PubMed: 9784581]

Ferreira C, Bucchini D, Martin ME, Levi S, Arosio P, Grandchamp B, Beaumont C. Early embryonic lethality of $\mathrm{H}$ ferritin gene deletion in mice. J Biol Chem 2000;275:3021-3024. [PubMed: 10652280]

Fleming RE, Migas MC, Holden CC, Waheed A, Britton RS, Tomatsu S, Bacon BR, Sly WS. Transferrin receptor 2: Continued expression in mouse liver in the face of iron overload and in hereditary hemochromatosis. Proc Natl Acad Sci USA 2000;97:2214-2219. [PubMed: 10681454]

Gaither LA, Eide DJ. The human ZIP1 transporter mediates zinc uptake in human K562 erythroleukemia cells. J Biol Chem 2001;276:22258-22264. [PubMed: 11301334] 
Ganz T. Molecular control of iron transport. J Am Soc Nephrol 2007;18:394-400. [PubMed: 17229910]

Gore A, Moran A, Hershfinkel M, Sekler I. Inhibitory mechanism of store-operated $\mathrm{Ca}^{2+}$ channels by zinc. J Biol Chem 2004;279:11106-11111. [PubMed: 14715648]

Guerinot ML. The ZIP family of metal transporters. Biochim Biophys Acta 2000;1465:190-198. [PubMed: 10748254]

Günes Ç, Heuchel R, Georgiev O, Müller KH, Lichtlen P, Blüthmann H, Marino S, Aguzzi A, Schaffner W. Embryonic lethality and liver degeneration in mice lacking the metal-responsive transcriptional activator MTF-1. EMBO J 1998;17:2846-2854. [PubMed: 9582278]

Gunshin H, Fujiwara Y, Custodio AO, Direnzo C, Robine S, Andrews NC. Slc11a2 is required for intestinal iron absorption and erythropoiesis but dispensable in placenta and liver. J Clin Invest 2005;115:1258-1266. [PubMed: 15849611]

Haase H, Maret W. Fluctuations of cellular, available zinc modulate insulin signaling via inhibition of protein tyrosine phosphatases. J Trace Elem Med Biol 2005;19:37-42. [PubMed: 16240670]

Haase H, Rink L. Signal transduction in monocytes: The role of zinc ions. Biometals 2007;20:579-585. [PubMed: 17453150]

Halliwell B, Gutteridge JM. Oxygen toxicity, oxygen radicals, transition metals and disease. Biochem J 1984;219:1-14. [PubMed: 6326753]

Hambidge M, Krebs NF. Interrelationships of key variables of human zinc homeostasis: Relevance to dietary zinc requirements. Annu Rev Nutr 2001;21:429-452. [PubMed: 11375444]

Hamza I, Faisst A, Prohaska J, Chen J, Gruss P, Gitlin JD. The metallochaperone Atox 1 plays a critical role in perinatal copper homeostasis. Proc Natl Acad Sci USA 2001;98:6848-6852. [PubMed: 11391006]

Hamza I, Gitlin JD. Copper chaperones for cytochrome c oxidase and human disease. J Bioenerg Biomembr 2002;34:381-388. [PubMed: 12539965]

Hamza I, Prohaska J, Gitlin JD. Essential role for Atox1 in the copper- mediated intracellular trafficking of the Menkes ATPase. Proc Natl Acad Sci USA 2003;100:1215-1220. [PubMed: 12538877]

Hansson A. Extracellular zinc ions induces mitogen-activated protein kinase activity and protein tyrosine phosphorylation in bombesin- sensitive Swiss 3 T3 fibroblasts. Arch Biochem Biophys 1996;328:233-238. [PubMed: 8644999]

Haremaki T, Fraser ST, Kuo YM, Baron MH, Weinstein DC. Vertebrate Ctr1 coordinates morphogenesis and progenitor cell fate and regulates embryonic stem cell differentiation. Proc Natl Acad Sci USA 2007;104:12029-12034. [PubMed: 17620605]

Harlin H, Reffey SB, Duckett CS, Lindsten T, Thompson CB. Characterization of XIAP-deficient mice. Mol Cell Biol 2001;21:3604-3608. [PubMed: 11313486]

Harris ZL, Takahashi Y, Miyajima H, Serizawa M, MacGillivray RT, Gitlin JD. Aceruloplasminemia: Molecular characterization of this disorder of iron metabolism. Proc Natl Acad Sci USA 1995;92:2539-2543. [PubMed: 7708681]

Hershfinkel M, Moran A, Grossman N, Sekler I. A zinc-sensing receptor triggers the release of intracellular $\mathrm{Ca}^{2+}$ and regulates ion transport. Proc Natl Acad Sci USA 2001;98:11749-11754. [PubMed: 11573009]

Horng YC, Leary SC, Cobine PA, Young FB, George GN, Shoubridge EA, Winge DR. Human Sco1 and Sco2 function as copper-binding proteins. J Biol Chem 2005;280:34113-34122. [PubMed: 16091356]

Huang LP, Gitschier J. A novel gene involved in zinc transport is deficient in the lethal milk mouse. Nat Genet 1997;17:292-297. [PubMed: 9354792]

Huang ZL, Dufner-Beattie J, Andrews GK. Expression and regulation of SLC39A family zinc transporters in the developing mouse intestine. Dev Biol 2006;295:571-579. [PubMed: 16682017]

Hurley LS, Keen CL, Lonnerdal B. Aspects of trace element interactions during development. Fed Proc 1983;42:1735-1739. [PubMed: 6832396]

Inoue K, Matsuda K, Itoh M, Kawaguchi H, Tomoike H, Aoyagi T, Nagai R, Hori M, Nakamura Y, Tanaka T. Osteopenia and male-specific sudden cardiac death in mice lacking a zinc transporter gene, Znt5. Hum Mol Genet 2002;11:1775-1784. [PubMed: 12095919] 
Johnson MB, Enns CA. Diferric transferrin regulates transferrin receptor 2 protein stability. Blood 2004;104:4287-4293. [PubMed: 15319290]

Kagara N, Tanaka N, Noguchi S, Hirano T. Zinc and its transporter ZIP10 are involved in invasive behavior of breast cancer cells. Cancer Sci 2007;98:692-697. [PubMed: 17359283]

Kagi JHR. Overview of metallothionein. Methods Enzymol 1991;205:613-626. [PubMed: 1779825]

Kambe T, Yamaguchi-Iwai Y, Sasaki R, Nagao M. Overview of mammalian zinc transporters. Cell Mol Life Sci 2004;61:49-68. [PubMed: 14704853]

Keen CL, Uriu-Hare JY, Hawk SN, Jankowski MA, Daston GP, Kwik- Uribe CL, Rucker RB. Effect of copper deficiency on prenatal development and pregnancy outcome. Am J Clin Nutr 1998;67:1003S1011S. [PubMed: 9587143]

Kelleher SL, Lonnerdal B. Marginal maternal Zn intake in rats alters mammary gland Cu transporter levels and milk $\mathrm{Cu}$ concentration and affects neonatal Cu metabolism. J Nutr 2003;133:2141-2148. [PubMed: 12840169]

Kelleher SL, Lonnerdal B. Mammary gland copper transport is stimulated by prolactin through alterations in Ctr1 and Atp7A localization. Am J Physiol Regul Integr Comp Physiol 2006a;291:R1181- R1191. [PubMed: 16741141]

Kelleher SL, Lonnerdal B. Zinc supplementation reduces iron absorption through age-dependent changes in small intestine iron transporter expression in suckling rat pups. J Nutr 2006b;136:1185-1191. [PubMed: 16614402]

Kim BE, Petris MJ. Phenotypic diversity of Menkes disease in mottled mice is associated with defects in localization and trafficking of the ATP7A protein. J Med Genet 2007;44:641-646. [PubMed: 17483305]

Kim S, Jung Y, Kim D, Koh H, Chung J. Extracellular zinc activates p70 S6 kinase through the phosphatidylinositol 3-kinase signaling pathway. J Biol Chem 2000;275:25979-25984. [PubMed: 10851233]

King JC, Shames DM, Woodhouse LR. Zinc homeostasis in humans. J Nutr 2000;130(Suppl):1360S1366S. [PubMed: 10801944]

Klein C, Sunahara RK, Hudson TY, Heyduk T, Howlett AC. Zinc inhibition of cAMP signaling. J Biol Chem 2002;277:11859-11865. [PubMed: 11805091]

Klomp AEM, Tops BBJ, Van den Berg IET, Berger R, Klomp LWJ. Biochemical characterization and subcellular localization of human copper transporter 1 (hCTR1). Biochem J 2002;364:497-505. [PubMed: 12023893]

Kordas K, Stoltzfus RJ. New evidence of iron and zinc interplay at the enterocyte and neural tissues. J Nutr 2004;134:1295-1298. [PubMed: 15173386]

Krezel A, Maret W. Dual nanomolar and picomolar Zn(II) binding properties of metallothionein. J Am Chem Soc 2007;129:10911-10921. [PubMed: 17696343]

Krishna SS, Majumdar I, Grishin NV. Structural classification of zinc fingers. Nucleic Acids Res 2003;31:532-550. [PubMed: 12527760]

Kuo YM, Gybina AA, Pyatskowit JW, Gitschier J, Prohaska JR. Copper transport protein (ctr1) levels in mice are tissue specific and dependent on copper status. J Nutr 2006;136:21-26. [PubMed: 16365053]

Kuo YM, Zhou B, Cosco D, Gitschier J. The copper transporter CTR1 provides an essential function in mammalian embryonic development. Proc Natl Acad Sci USA 2001;98:6836-6841. [PubMed: 11391004]

Kury S, Dreno B, Bezieau S, Giraudet S, Khar M, Kamoun R, Moisan JP. Identification of SLC39A4, a gene involved in acrodermatitis enteropathica. Nat Genet 2002;31:239-240. [PubMed: 12068297]

Laity JH, Andrews GK. Understanding the mechanisms of zincsensing by metal-response element binding transcription factor (MTF-1). Arch Biochem Biophys 2007;463:201-210. [PubMed: 17462582]

Lam-Yuk-Tseung S, Picard V, Gros P. Identification of a tyrosinebased motif (YGSI) in the amino terminus of Nramp1 (Slc11a1) that is important for lysosomal targeting. J Biol Chem 2006;281:31677-31688. [PubMed: 16905747]

Langmade SJ, Ravindra R, Daniels PJ, Andrews GK. The transcription factor MTF-1 mediates metal regulation of the mouse ZnT1 gene. J Biol Chem 2000;275:34803-34809. [PubMed: 10952993] 
Lee LW, Prohaska JR, Thiele DJ. Essential role for mammalian copper transporter Ctr1 in copper homeostasis and embryonic development. Proc Natl Acad Sci USA 2001;98:6842-6847. [PubMed: 11391005]

Levy JE, Jin O, Fujiwara Y, Kuo F, Andrews NC. Transferrin receptor is necessary for development of erythrocytes and the nervous system. Nat Genet 1999;21:396-399. [PubMed: 10192390]

Li M, Zhang Y, Liu Z, Bharadwaj U, Wang H, Wang X, Zhang S, Liuzzi JP, Chang SM, Cousins RJ, Fisher WE, Brunicardi FC, Logsdon CD, Chen C, Yao Q. Aberrant expression of zinc transporter ZIP4 (SLC39A4) significantly contributes to human pancreatic cancer pathogenesis and progression. Proc Natl Acad Sci USA 2007;104:18636-18641. [PubMed: 18003899]

Lichtlen P, Schaffner W. Putting its fingers on stressful situations: The heavy metal-regulatory transcription factor MTF-1. Bioessays 2001;23:1010-1017. [PubMed: 11746217]

Lill R, Dutkiewicz R, Elsasser HP, Hausmann A, Netz DJ, Pierik AJ, Stehling O, Urzica E, Muhlenhoff U. Mechanisms of iron-sulfur protein maturation in mitochondria, cytosol and nucleus of eukaryotes. Biochim Biophys Acta 2006;1763:652-667. [PubMed: 16843540]

Lutsenko S, Barnes NL, Bartee MY, Dmitriev OY. Function and regulation of human copper-transporting ATPases. Physiol Rev 2007;87:1011-1046. [PubMed: 17615395]

Machen M, Montgomery T, Holland R, Braselton E, Dunstan R, Brewer G, Yuzbasiyan-Gurkan V. Bovine hereditary zinc deficiency: Lethal trait A 46. J Vet Diagn Invest 1996;8:219-227. [PubMed: 8744744]

Madsen E, Gitlin JD. Copper deficiency. Curr Opin Gastroenterol 2007;23:187-192. [PubMed: 17268249]

Maine GN, Burstein E. COMMD proteins: COMMing to the scene. Cell Mol Life Sci 2007;64:19972005. [PubMed: 17497243]

Maret W. Crosstalk of the group IIa and IIb metals calcium and zinc in cellular signaling. Proc Natl Acad Sci USA 2001;98:12325-12327. [PubMed: 11675482]

Maret W, Krezel A. Cellular zinc and redox buffering capacity of metallothionein/thionein in health and disease. Mol Med 2007;13:371-375. [PubMed: 17622324]

Martelli A, Wattenhofer-Donze M, Schmucker S, Bouvet S, Reutenauer L, Puccio H. Frataxin is essential for extramitochondrial Fe-S cluster proteins in mammalian tissues. Hum Mol Genet 2007;16:26512658. [PubMed: 17597094]

Maryon EB, Molloy SA, Zimnicka AM, Kaplan JH. Copper entry into human cells: Progress and unanswered questions. Biometals 2007;20:355-364. [PubMed: 17211679]

Mathews WR, Wang F, Eide DJ, Van Doren M. Drosophila fear of intimacy Encodes a Zrt/IRT-like Protein (ZIP) Family Zinc Transporter Functionally Related to Mammalian ZIP Proteins. J Biol Chem 2005;280:787-795. [PubMed: 15509557]

Maverakis E, Fung MA, Lynch PJ, Draznin M, Michael DJ, Ruben B, Fazel N. Acrodermatitis enteropathica and an overview of zinc metabolism. J Am Acad Dermatol 2007;56:116-124. [PubMed: 17190629]

McClain CJ. The pancreas and zinc homeostasis. J Lab Clin Med 1990;116:275-276. [PubMed: 2401844]

Mendelsohn BA, Yin C, Johnson SL, Wilm TP, Solnica-Krezel L, Gitlin JD. Atp7a determines a hierarchy of copper metabolism essential for notochord development. Cell Metab 2006;4:155-162. [PubMed: 16890543]

Mercer JF. Menkes syndrome and animal models. Am J Clin Nutr 1998;67:1022S-1028S. [PubMed: 9587146]

Miret S, Simpson RJ, McKie AT. Physiology and molecular biology of dietary iron absorption. Annu Rev Nutr 2003;23:283-301. [PubMed: 12626689]

Moore LA, Broihier HT, Van Doren M, Lunsford LB, Lehmann R. Identification of genes controlling germ cell migration and embryonic gonad formation in Drosophila. Development 1998;125:667678. [PubMed: 9435287]

Mufti AR, Burstein E, Duckett CS. XIAP:cell death regulation meets copper homeostasis. Arch Biochem Biophys 2007;463:168-174. [PubMed: 17382285]

Muhlenhoff U, Richhardt N, Ristow M, Kispal G, Lill R. The yeast frataxin homolog Yfh1p plays a specific role in the maturation of cellular Fe/S proteins. Hum Mol Genet 2002;11:2025-2036. [PubMed: 12165564] 
Muramatsu Y, Yamada T, Miura M, Sakai T, Suzuki Y, Serikawa T, Tanzi RE, Matsumoto K. Wilson's disease gene is homologous to hts causing abnormal copper transport in Long-Evans Cinnamon rats. Gastroenterology 1994;107:1189-1192. [PubMed: 7926469]

Niciu MJ, Ma XM, El Meskini R, Pachter JS, Mains RE, Eipper BA. Altered ATP7A expression and other compensatory responses in a murine model of Menkes disease. Neurobiol Dis 2007;27:278291. [PubMed: 17588765]

Norgate M, Lee E, Southon A, Farlow A, Batterham P, Camakaris J, Burke R. Essential roles in development and pigmentation for the Drosophila copper transporter DmATP7. Mol Biol Cell 2006;17:475-484. [PubMed: 16251357]

Nose Y, Kim BE, Thiele DJ. Ctr1 drives intestinal copper absorption and is essential for growth, iron metabolism, and neonatal cardiac function. Cell Metab 2006;4:235-244. [PubMed: 16950140]

Nyasae L, Bustos R, Braiterman L, Eipper B, Hubbard A. Dynamics of endogenous ATP7A (Menkes protein) in intestinal epithelial cells: Copper-dependent redistribution between two intracellular sites. Am J Physiol Gastrointest Liver Physiol 2007;292:G1181-G1194. [PubMed: 17158254]

Ohana E, Sekler I, Kaisman T, Kahn N, Cove J, Silverman WF, Amsterdam A, Hershfinkel M. Silencing of ZnT-1 expression enhances heavy metal influx and toxicity. J Mol Med 2006;84:753-763. [PubMed: 16741752]

Ohgami RS, Campagna DR, Antiochos B, Wood EB, Sharp JJ, Barker JE, Fleming MD. nm1054: A spontaneous, recessive, hypochromic, microcytic anemia mutation in the mouse. Blood 2005;106:3625-3631. [PubMed: 15994289]

Ohgami RS, Campagna DR, McDonald A, Fleming MD. The Steap proteins are metalloreductases. Blood 2006;108:1388-1394. [PubMed: 16609065]

Palmiter RD. Protection against zinc toxicity by metallothionein and zinc transporter 1. Proc Natl Acad Sci USA 2004;101:4918-4923. [PubMed: 15041749]

Palmiter RD, Huang L. Efflux and compartmentalization of zinc by members of the SLC30 family of solute carriers. Pflugers Arch - Eur J Physiol 2004;447:744-751. [PubMed: 12748859]

Papadopoulou LC, Sue CM, Davidson MM, Tanji K, Nishino I, Sadlock JE, Krishna S, Walker W, Selby J, Glerum DM, Coster RV, Lyon G, Scalais E, Lebel R, Kaplan P, Shanske S, De Vivo DC, Bonilla E, Hirano M, DiMauro S, Schon EA. Fatal infantile cardioencephalomyopathy with COX deficiency and mutations in SCO2, a COX assembly gene. Nat Genet 1999;23:333-337. [PubMed: 10545952]

Pena MM, Lee J, Thiele DJ. A delicate balance: Homeostatic control of copper uptake and distribution. J Nutr 1999;129:1251-1260. [PubMed: 10395584]

Peters JL, Dufner-Beattie J, Xu W, Geiser J, Lahner B, Salt DE, Andrews GK. Targeting of the mouse Slc39a2 (Zip2) gene reveals highly cell-specific patterns of expression, and unique functions in zinc, iron and calcium homeostasis. Genesis 2007;45:339-352. [PubMed: 17506078]

Petris MJ, Smith K, Lee J, Thiele DJ. Copper-stimulated endocytosis and degradation of the human copper transporter, hCtr1. J Biol Chem 2003;278:9639-9646. [PubMed: 12501239]

Peyssonnaux C, Zinkernagel AS, Schuepbach RA, Rankin E, Vaulont S, Haase VH, Nizet V, Johnson RS. Regulation of iron homeostasis by the hypoxia-inducible transcription factors (HIFs). J Clin Invest 2007;117:1926-1932. [PubMed: 17557118]

Pondarre C, Antiochos BB, Campagna DR, Clarke SL, Greer EL, Deck KM, McDonald A, Han AP, Medlock A, Kutok JL, Anderson SA, Eisenstein RS, Fleming MD. The mitochondrial ATP-binding cassette transporter Abcb7 is essential in mice and participates in cytosolic iron-sulfur cluster biogenesis. Hum Mol Genet 2006;15:953-964. [PubMed: 16467350]

Prohaska JR, Gybina AA. Intracellular copper transport in mammals. J Nutr 2004;134:1003-1006. [PubMed: 15113935]

Qiu A, Jansen M, Sakaris A, Min SH, Chattopadhyay S, Tsai E, Sandoval C, Zhao R, Akabas MH, Goldman ID. Identification of an intestinal folate transporter and the molecular basis for hereditary folate malabsorption. Cell 2006;127:917-928. [PubMed: 17129779]

Ravasi T, Huber T, Zavolan M, Forrest A, Gaasterland T, Grimmond S, Hume DA, RIKEN GG, Members GSL. Systematic characterization of the zinc-finger-containing proteins in the mouse transcriptome. Genome Res 2003;13:1430-1442. [PubMed: 12819142]

Robb A, Wessling-Resnick M. Regulation of transferrin receptor 2 protein levels by transferrin. Blood 2004;104:4294-4299. [PubMed: 15319276] 
Sacconi S, Trevisson E, Pistollato F, Baldoin MC, Rezzonico R, Bourget I, Desnuelle C, Tenconi R, Basso G, DiMauro S, Salviati L. hCOX18 and hCOX19: Two human genes involved in cytochrome c oxidase assembly. Biochem Biophys Res Commun 2005;337:832-839. [PubMed: 16212937]

Samet JM, Dewar BJ, Wu WD, Graves LM. Mechanisms of $\mathrm{Zn}^{2+}$ - induced signal initiation through the epidermal growth factor receptor. Toxicol Appl Pharmacol 2003;191:86-93. [PubMed: 12915106]

Schoenfeld RA, Napoli E, Wong A, Zhan S, Reutenauer L, Morin D, Buckpitt AR, Taroni F, Lonnerdal B, Ristow M, Puccio H, Cortopassi GA. Frataxin deficiency alters heme pathway transcripts and decreases mitochondrial heme metabolites in mammalian cells. Hum Mol Genet 2005;14:37873799. [PubMed: 16239244]

Segal D, Ohana E, Besser L, Hershfinkel M, Moran A, Sekler I. A role for ZnT-1 in regulating cellular cation influx. Biochem Biophys Res Commun 2004;323:1145-1150. [PubMed: 15451416]

Seve M, Chimienti F, Devergnas S, Favier A. In silico identification and expression of SLC30 family genes: An expressed sequence tag data mining strategy for the characterization of zinc transporters' tissue expression. BMC Genomics 2004;5:32. [PubMed: 15154973]

Shaw GC, Cope JJ, Li L, Corson K, Hersey C, Ackermann GE, Gwynn B, Lambert AJ, Wingert RA, Traver D, Trede NS, Barut BA, Zhou Y, Minet E, Donovan A, Brownlie A, Balzan R, Weiss MJ, Peters LL, Kaplan J, Zon LI, Paw BH. Mitoferrin is essential for erythroid iron assimilation. Nature 2006;440:96-100. [PubMed: 16511496]

Shim H, Harris ZL. Genetic defects in copper metabolism. J Nutr 2003;133:1527S-1531S. [PubMed: 12730458]

Silvestri L, Pagani A, Camaschella C. Furin mediated release of soluble hemojuvelin: A new link between hypoxia and iron homeostasis. Blood 2008;111:924-931. [PubMed: 17938254]

Smith SR, Cooperman S, Lavaute T, Tresser N, Ghosh M, Meyron-Holtz E, Land W, Ollivierre H, Jortner B, Switzer R III, Messing A, Rouault TA. Severity of neurodegeneration correlates with compromise of iron metabolism in mice with iron regulatory protein deficiencies. Ann NYAcad Sci 2004;1012:65-83.

Smith SR, Ghosh MC, Ollivierre-Wilson H, Hang TW, Rouault TA. Complete loss of iron regulatory proteins 1 and 2 prevents viability of murine zygotes beyond the blastocyst stage of embryonic development. Blood Cells Mol Dis 2006;36:283-287. [PubMed: 16480904]

Suzuki T, Ishihara K, Migaki H, Ishihara K, Nagao M, Yamaguchi-Iwai Y, Kambe T. Two different zinc transport complexes of cation diffusion facilitator proteins localized in the secretory pathway operate to activate alkaline phosphatases in vertebrate cells. J Biol Chem 2005a;280:30956-30962. [PubMed: 15994300]

Suzuki T, Ishihara K, Migaki H, Matsuura W, Kohda A, Okumura K, Nagao M, Yamaguchi-Iwai Y, Kambe T. Zinc transporters, ZnT5 and ZnT7, are required for the activation of alkaline phosphatases, zinc-requiring enzymes that are glycosylphosphatidylinositol- anchored to the cytoplasmic membrane. J Biol Chem 2005b;280:637-643. [PubMed: 15525635]

Takahashi Y, Kako K, Kashiwabara S, Takehara A, Inada Y, Arai H, Nakada K, Kodama H, Hayashi J, Baba T, Munekata E. Mammalian copper chaperone Cox 17p has an essential role in activation of cytochrome c oxidase and embryonic development. Mol Cell Biol 2002;22:7614-7621. [PubMed: 12370308]

Tao TY, Liu F, Klomp L, Wijmenga C, Gitlin JD. The copper toxicosis gene product Murr1 directly interacts with the Wilson disease protein. J Biol Chem 2003;278:41593-41596. [PubMed: 12968035]

Taylor KM, Nicholson RI. The LZT proteins; the LIV-1 subfamily of zinc transporters. Biochim Biophys Acta 2003;1611:16-30. [PubMed: 12659941]

Touret N, Martin-Orozco N, Paroutis P, Furuya W, Lam-Yuk-Tseung S, Forbes J, Gros P, Grinstein S. Molecular and cellular mechanisms underlying iron transport deficiency in microcytic anemia. Blood 2004;104:1526-1533. [PubMed: 15155465]

Turski ML, Thiele DJ. Drosophila Ctr1A functions as a copper transporter essential for development. J Biol Chem 2007;282:24017-24026. [PubMed: 17573340]

Vallee BL, Auld DS. Zinc coordination, function, and structure of zinc enzymes and other proteins. Biochemistry 1990;29:5647-5659. [PubMed: 2200508] 
Valnot I, Osmond S, Gigarel N, Mehaye B, Amiel J, Cormier-Daire V, Munnich A, Bonnefont JP, Rustin $\mathrm{P}$, Rotig A. Mutations of the SCO1 gene in mitochondrial cytochrome c oxidase deficiency with neonatal-onset hepatic failure and encephalopathy. Am J Hum Genet 2000;67:1104-1109. [PubMed: 11013136]

Van de Sluis B, Muller P, Duran K, Chen A, Groot AJ, Klomp LW, Liu PP, Wijmenga C. Increased activity of hypoxia-inducible factor 1 is associated with early embryonic lethality in Commd 1 null mice. Mol Cell Biol 2007;27:4142-4156. [PubMed: 17371845]

Van de Sluis B, Rothuizen J, Pearson PL, van Oost BA, Wijmenga C. Identification of a new copper metabolism gene by positional cloning in a purebred dog population. Hum Mol Genet 2002;11:165173. [PubMed: 11809725]

Van Hoof F, Den Tandt W, Scharpe S. Wilson's disease: Hypothesis of a deficiency of copper excretion via the endosome to the bile. Arch Neurol 1992;49:800. [PubMed: 1524511]

Vazzola V, Losa A, Soave C, Murgia I. Knockout of frataxin gene causes embryo lethality in Arabidopsis. FEBS Lett 2007;581:667-672. [PubMed: 17258206]

vonBulow V, Dubben S, Engelhardt G, Hebel S, Plumakers B, Heine H, Rink L, Haase H. Zinc-dependent suppression of TNF- $\{$ alpha $\}$ production is mediated by protein kinase A-induced inhibition of Raf-1, I\{kappa\}B kinase beta, and NF-\{kappa\}B. J Immunol 2007;179:4180-4186. [PubMed: 17785857]

Wallace DF, Summerville L, Crampton E, Subramaniam VN. Defective trafficking and localization of mutated transferrin receptor 2: Implications for type 3 hereditary hemochromatosis. Am J Physiol Cell Physiol 2008;294:C383-C390. [PubMed: 18094142]

Wallace DF, Summerville L, Subramaniam VN. Targeted disruption of the hepatic transferrin receptor 2 gene in mice leads to iron overload. Gastroenterology 2007;132:301-310. [PubMed: 17241880]

Wallace DF, Tonks ID, Zournazi A, Kay GF, Subramaniam VN. Inactivation of the murine transferrin receptor 2 gene using the Cre recombinase: LoxP system. Genesis 2004;39:38-41. [PubMed: 15124225]

Wang F, Dufner-Beattie J, Kim BE, Petris MJ, Andrews G, Eide DJ. Zinc-stimulated endocytosis controls activity of the mouse ZIP1 and ZIP3 zinc uptake transporters. J Biol Chem 2004;279:24631-24639. [PubMed: 15054103]

Wang K, Zhou B, Kuo YM, Zemansky J, Gitschier J. A novel member of a zinc transporter family is defective in acrodermatitis enteropathica. Am J Hum Genet 2002;71:66-73. [PubMed: 12032886]

Wang Y, Wimmer U, Lichtlen P, Inderbitzin D, Stieger B, Meier PJ, Hunziker L, Stallmach T, Forrer R, Rulicke T, Georgiev O, Schaffner W. Metal-responsive transcription factor-1 (MTF-1) is essential for embryonic liver development and heavy metal detoxification in the adult liver. FASEB J 2004;18:1071-1079. [PubMed: 15226267]

Weaver BP, Dufner-Beattie J, Kambe T, Andrews GK. Novel zincresponsive post-transcriptional mechanisms reciprocally regulate expression of the mouse Slc39a4 and Slc39a5 zinc transporters (Zip4 and Zip5). Biol Chem 2007;388:1301-1312. [PubMed: 18020946]

Wimmer U, Wang Y, Georgiev O, Schaffner W. Two major branches of anti-cadmium defense in the mouse: MTF-1/metallothioneins and glutathione. Nucleic Acids Res 2005;33:5715-5727. [PubMed: 16221973]

Wingert RA, Brownlie A, Galloway JL, Dooley K, Fraenkel P, Axe JL, Davidson AJ, Barut B, Noriega L, Sheng X, Zhou Y, Zon LI. The chianti zebrafish mutant provides a model for erythroid-specific disruption of transferrin receptor 1. Development 2004;131:6225-6235. [PubMed: 15563524]

Wrighting DM, Andrews NC. Interleukin-6 induces hepcidin expression through STAT3. Blood 2006;108:3204-3209. [PubMed: 16835372]

Yamaji S, Tennant J, Tandy S, Williams M, Srai SKS, Sharp P. Zinc regulates the function and expression of the iron transporters DMT1 and IREG1 in human intestinal Caco-2 cells. FEBS Lett 2001;507:137-141. [PubMed: 11684086]

Yamasaki S, Sakata-Sogawa K, Hasegawa A, Suzuki T, Kabu K, Sato E, Kurosaki T, Yamashita S, Tokunaga M, Nishida K, Hirano T. Zinc is a novel intracellular second messenger. J Cell Biol 2007;177:637-645. [PubMed: 17502426] 
Yamashita S, Miyagi C, Fukada T, Kagara N, Che YS, Hirano T. Zinc transporter LIVI controls epithelialmesenchymal transition in zebrafish gastrula organizer. Nature 2004;429:298-302. [PubMed: 15129296]

Zhang Y, Aizenman E, DeFranco DB, Rosenberg PA. Intracellular zinc release, 12-lipoxygenase activation and MAPK dependent neuronal and oligodendroglial death. Mol Med 2007;13:350-355. [PubMed: 17622306]

Zhao L, Chen W, Taylor KM, Cai B, Li X. LIV-1 suppression inhibits HeLa cell invasion by targeting ERK1/2-Snail/Slug pathway. Biochem Biophys Res Commun 2007;363:82-88. [PubMed: 17825787]

Zimnicka AM, Maryon EB, Kaplan JH. Human copper transporter hCTR1 mediates basolateral uptake of copper into enterocytes: Implications for copper homeostasis. J Biol Chem 2007;282:2647126480. [PubMed: 17627945]

Zohn IE, De DI, Pollock A, Ward DM, Goodman JF, Liang X, Sanchez AJ, Niswander L, Kaplan J. The flatiron mutation in mouse ferroportin acts as a dominant negative to cause ferroportin disease. Blood 2007;109:4174-4180. [PubMed: 17289807] 


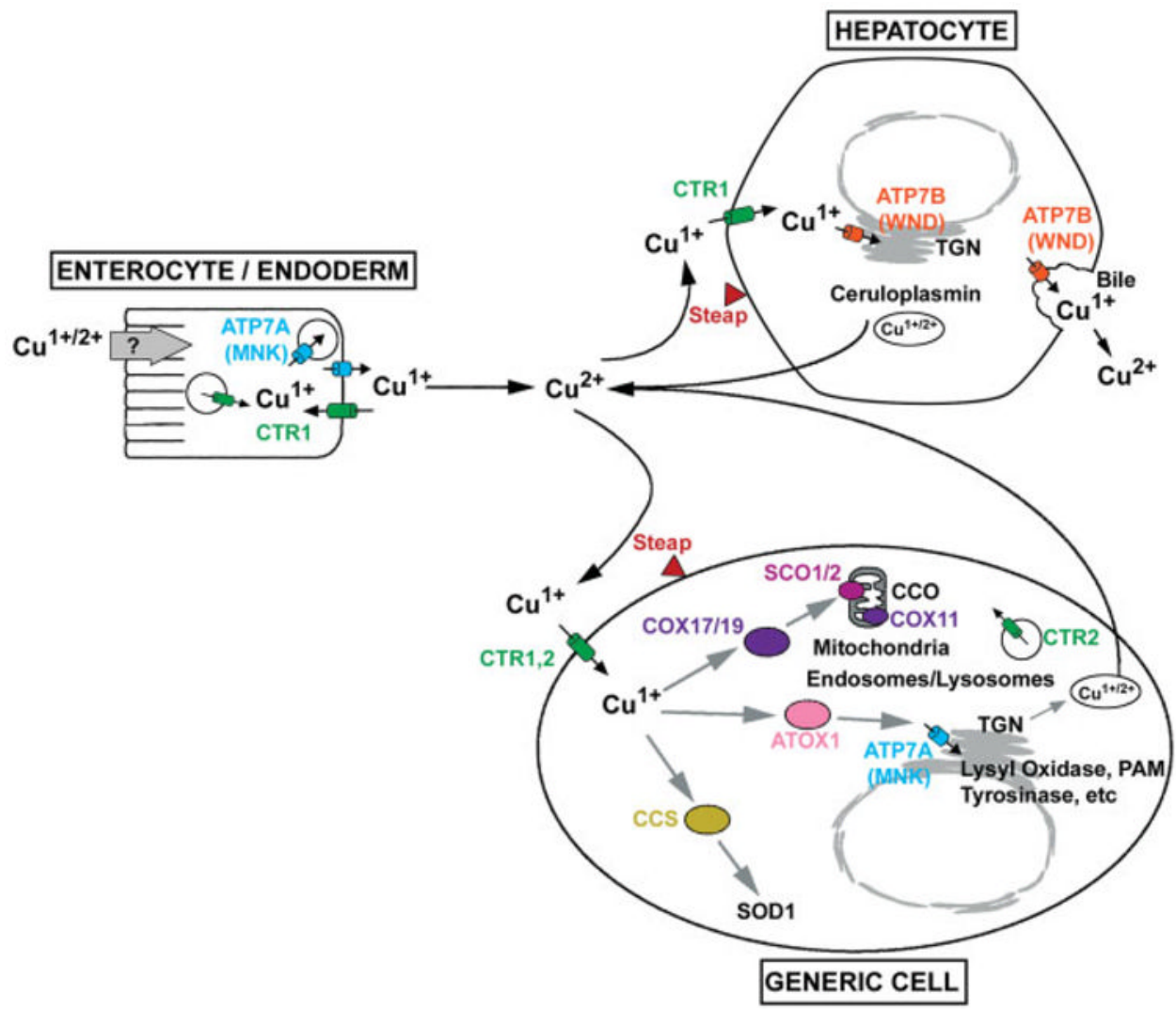

FIG. 1.

Overview of copper homeostasis. Copper is oxidized $\left(\mathrm{Cu}^{2+}\right)$ in the intestinal lumen and in the serum, but is reduced to $\mathrm{Cu}^{1+}$ before transport into cells. The Steap ferric/cupric reductases (Steaps 2, 3, and 4) are localized to endosomes/lysosomes and the plasma membrane and may be essential for the reduction of copper, as well as the reduction of iron (Ohgami et al., 2006). Copper is transported into ENTEROCYTE/ENDODERM cells by unknown mechanisms (endocytosis?). CTR1 is essential for the acquisition of dietary copper but its function in the enterocyte is unknown. In many other cell types (GENERIC CELL), copper is taken up by CTR1 localized to the plasma membrane and perhaps also by CTR2 (Slc31a2). Copper taken up by ENTEROCYTE/ENDODERM is exported into portal blood/conceptus, respectively, by ATP7A (Menkes disease protein, MNK) which is localized to vesicles trafficking toward the basolateral membrane and to the basolateral membrane. Copper exported to portal blood is taken up into the liver, the primary organ that regulates copper homeostasis. In the HEPATOCYTE, ATP7B (Wilson's disease protein, WND) effluxes excess copper into the bile and puts copper into the trans-Golgi network (TGN) where it is loaded into ceruloplasmin, a ferroxidase that is the primary copper binding protein in serum. Inside the cell (GENERIC CELL), copper is distributed to cytoplasmic copper chaperones (COX17/19, ATOX1, CCS) which, in turn, deliver copper to mitochondrial inner membrane and ultimately cytochrome C oxidase (CCO) or to ATP7A in the TGN, and cytoplasmic SOD1, respectively. The assembly of copper into CCO is an active area of investigation. It is thought that copper in COX17/19 (and probably COX23/MTCP1) is first transferred to both COX11 and SCO1/2 and ultimately to CCO. ATP7A transports copper into the TGN and activates copper containing secretory and membrane-bound proteins [lysyl oxidase, tyrosinase, peptidylglycine $\alpha$ amidating monooxygenase (PAM)]. It should be noted that the cellular localization and abundance of CTR1, ATP7A, and ATP7B are dynamically regulated by copper availability which is not reflected in this static cartoon. 


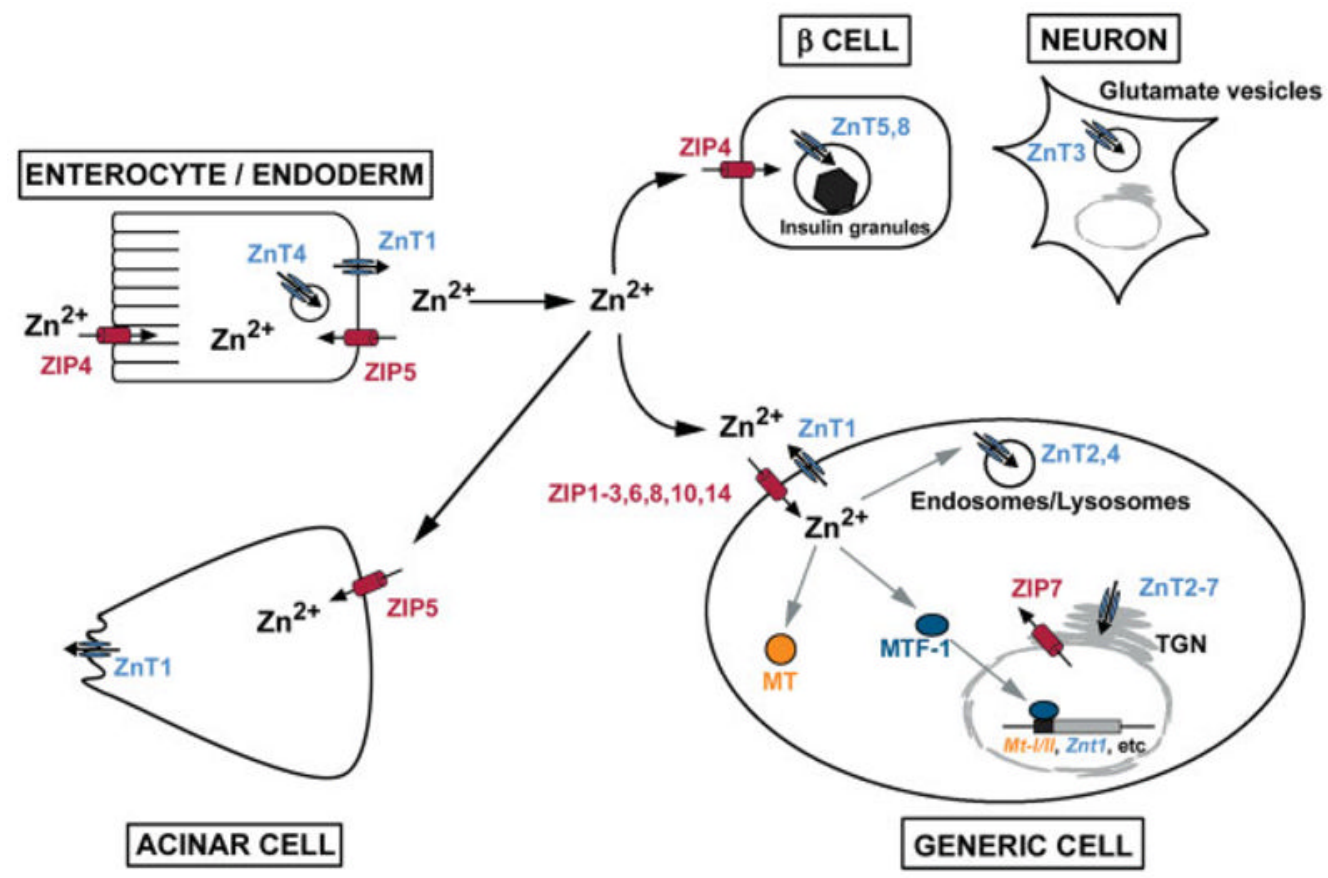

FIG. 2.

Overview of zinc homeostasis. Twenty four different genes encode proteins that may be involved in the uptake (Zip genes) or efflux (ZnT genes) of this metal in a cell-specific, developmentally regulated, and zinc-regulated manner. The functions of many of these genes remain to be determined. Therefore, this cartoon provides only a superficial and static view of zinc homeostasis. ZIP4 plays a critical role in the absorption of dietary zinc by ENTEROCYTE/ ENDODERM cells when zinc is limiting, but other transporters must also play important roles. Zinc is thought to be exported into portal blood or into the conceptus by ZnT1 localized on the basolateral membrane. Other ZnT proteins (i.e. ZnT4) also likely play a role in this process. ZIP5 is localized to the basolateral membranes of enterocytes, endoderm cells and pancreatic acinar cells where it may serve to remove zinc from the blood when zinc is replete. In peripheral tissues (GENERIC CELL), zinc is probably taken up by various ZIP transporters localized on the plasma membrane. To date ZIPs1, 2, 3, 6, 8, 10, and 14 have each been shown to have zinc transport activity in transfection or oocyte injection studies, and most show tissue-specific patterns of expression. Inside the cell, free zinc levels are kept low and zinc can be bound to MT or transported into secretory vesicles, endosomes/lysosomes or zincosomes by ZnT2 and ZnT4. Zinc activates the zinc-sensing transcription factor MTF-1 which regulates transcription of the mouse Mt-I/II and Zntl genes and represses expression of Zip10 in an effort to control excess zinc. ZnTs2-7 participate in the delivery of zinc into the secretory pathway, whereas ZIP7 may transport zinc out of the Golgi apparatus into the cytoplasm. ZnT3 transports zinc into glutamate containing vesicles in the brain whereas ZnT8 transports zinc into pancreatic $\beta$-cell insulin secretory granules. ZIP4 is expressed in $\beta$-cells, but its localization in those cells has not been reported. 


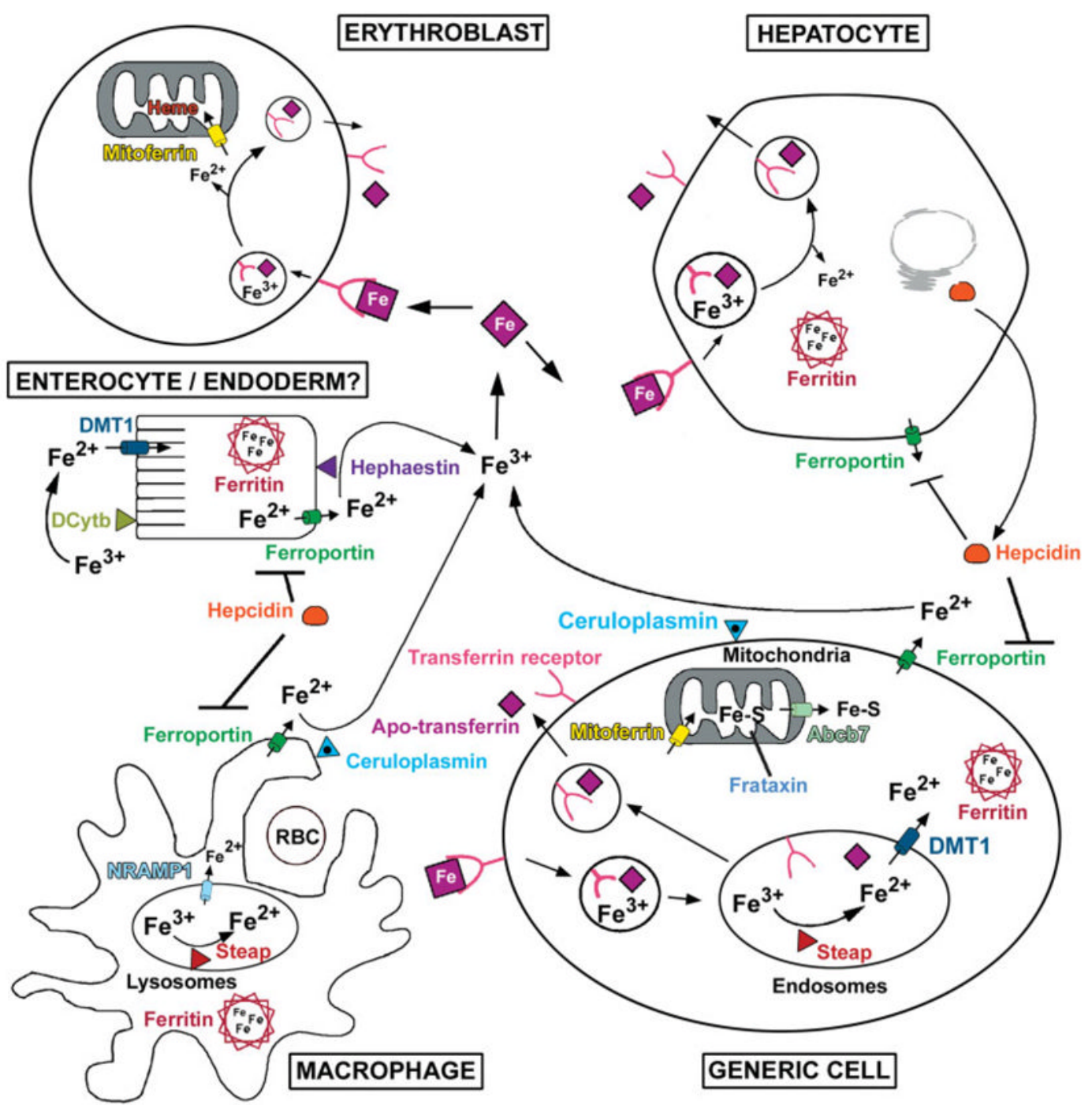

FIG. 3.

Overview of iron homeostasis. Iron is oxidized $\left(\mathrm{Fe}^{3+}\right)$ in the intestinal lumen and in the serum, but is reduced $\left(\mathrm{Fe}^{2+}\right)$ before transport into cells. Iron $\left(\mathrm{Fe}^{2+}\right)$ is transported into ENTEROCYTES by DMT1 after extracellular reduction perhaps by DCytb. Iron uptake by visceral ENDODERM cells is apparently not dependent on DMT1 and could require the transferrin uptake system. Iron is transported out of cells by Ferroportin and is thought to be subsequently oxidized $\left(\mathrm{Fe}^{3+}\right)$ by membrane bound Hephaestin and Ceruloplasmin. Iron, inflammation and hypoxia regulate Hepcidin, a polypeptide hormone made by the HEPATOCYTE. Hepcidin binds to Ferroportin resulting in degradation of the transporter. In the serum, $\mathrm{Fe}^{3+}$ binds to Transferrin. Developing ERYTHROBLASTS (heme is the major pool of iron) and many other cell types take up iron via the transferrin-mediated endocytic pathway (see GENERIC CELL). After binding to the transferrin receptor, the iron-transferrin complex is internalized and iron is released from transferrin in the acidified endosome, reduced by a Steap metalloreductase and then transported into the cytoplasm by DMT1. Apo-transferrin and the transferrin receptor are returned to circulation and plasma membrane, respectively, via the recycling endosome pathway. All nonerythroid cells store iron complexed with the ferritin heavy and light chains (Ferritin) which can store up to 4,000 atoms of iron per molecule. Cytoplasmic iron is transported into mitochondria by mitoferrin where it is loaded into $\mathrm{Fe}-\mathrm{S}$ 
clusters in a process that requires Frataxin. A substrate essential for Fe-S assembly in the cytoplasm is transported out of the mitochondria by the ATP-binding cassette transporter ABCB7 (see GENERIC CELL). In the erythroblast, mitochondrial iron is primarily utilized for heme synthesis. A major fraction of iron is recycled by the reticulo-endothelial MACROPHAGE which phagocytoses aged red blood cells (RBC). The iron is solubilized in the lysosomes, reduced by a Steap metalloreductase and exported out of the lysosome by NRAMP1. Iron is released from the macrophage by ferroportin, subsequently reoxidized by Ceruloplasmin, and conveyed again via transferrin through the systemic circulation. 
Table 1

Phenotypes of Animals With Mutations in Genes Critical for Copper Homeostasis During Development

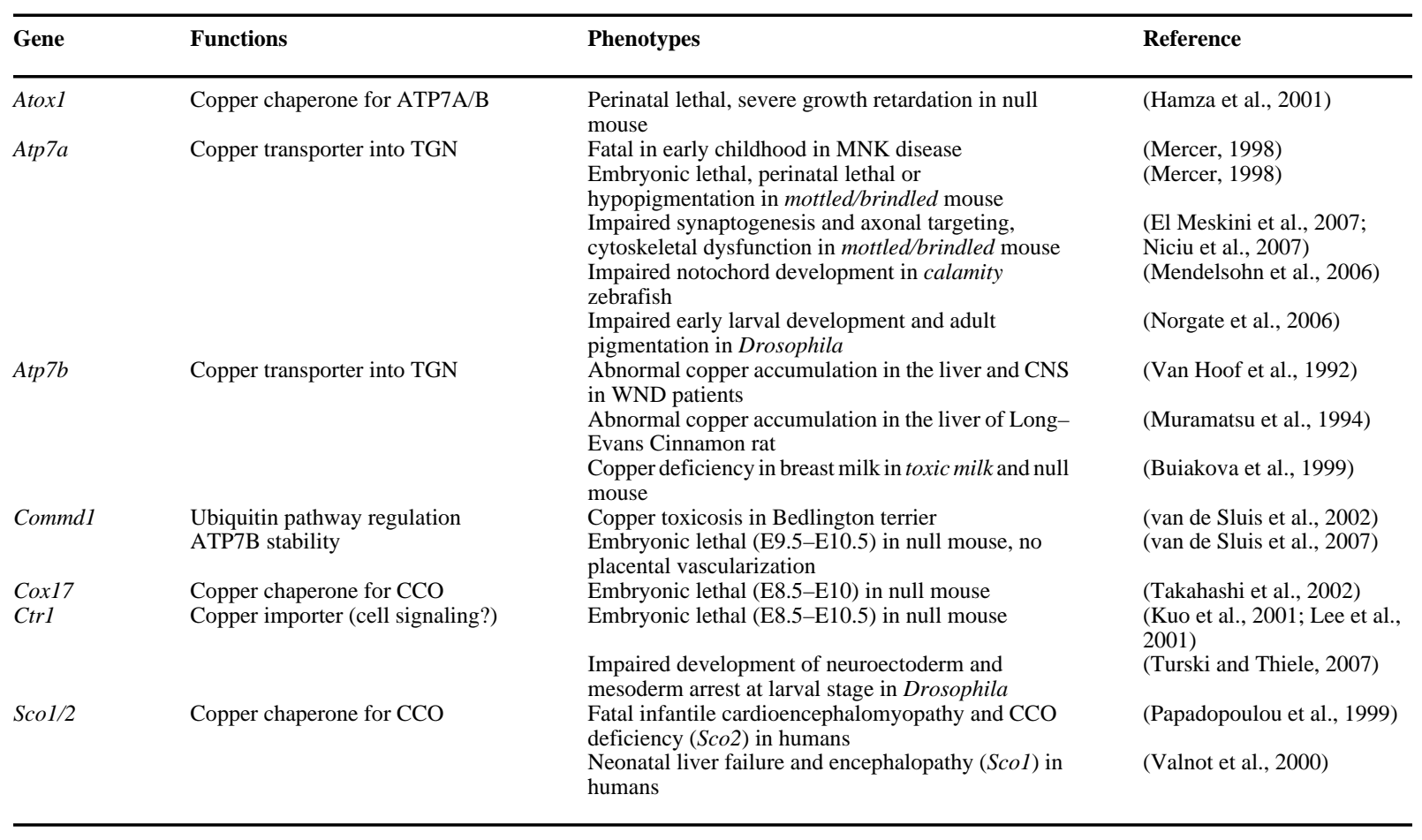


Table 2

Phenotypes of Animals With Mutations in Genes Critical for Zinc Homeostasis During Development

\begin{tabular}{|c|c|c|c|}
\hline Gene & Functions & Phenotypes & Reference \\
\hline$M t-I / I I$ & Zinc buffer-pool & $\begin{array}{l}\text { Increased embryo sensitivity to zinc deficiency in null } \\
\text { mouse and increased resistance to zinc deficiency } \\
\text { when over-expressed }\end{array}$ & $\begin{array}{l}\text { (Andrews and Geiser, 1999) } \\
\text { (Dalton et al., 1996) }\end{array}$ \\
\hline$M t f-1$ & Zinc-sensing transcription factor & $\begin{array}{l}\text { Embryonic lethal (E14) due to liver degeneration in } \\
\text { null mouse }\end{array}$ & (Wang et al., 2004) \\
\hline Zipl & Zinc importer & $\begin{array}{l}\text { Impaired embryonic adaptation to zinc deficiency in } \\
\text { null mouse }\end{array}$ & (Dufner-Beattie et al., 2006) \\
\hline Zip2 & Zinc importer & $\begin{array}{l}\text { Impaired embryonic adaptation to zinc deficiency and } \\
\text { altered iron and calcium homeostasis in null mouse } \\
\text { during zinc }\end{array}$ & (Peters et al., 2007) \\
\hline Zip3 & Zinc importer & $\begin{array}{l}\text { Impaired embryonic adaptation to zinc deficiency (cell } \\
\text { type-specific) in null mouse }\end{array}$ & (Dufner-Beattie et al., 2005) \\
\hline Zip4 & Zinc importer & $\begin{array}{l}\text { Childhood lethal acrodermatitis enteropathica in } \\
\text { humans } \\
\text { Embryonic lethal (E8-E9) in homozygous null mouse } \\
\text { and hypersensitivity to zinc deficiency in heterozygous } \\
\text { null mice }\end{array}$ & $\begin{array}{l}\text { (Maverakis et al., 2007) } \\
\text { (Dufner-Beattie et al., 2007) }\end{array}$ \\
\hline & & Lethal trait A46 in bovine (Zip4?) & (Machen et al., 1996) \\
\hline Liv-1 like & Zinc importer & $\begin{array}{l}\text { Impaired epithelial-mesenchymal transition in } \\
\text { zebrafish gastrula (zLIV-1) } \\
\text { Impaired germ cell migration and gonad } \\
\text { morphogenesis in Drosophila (Fear of intimacy) }\end{array}$ & $\begin{array}{l}\text { (Yamashita et al., 2004) } \\
\text { (Moore et al., 1998) }\end{array}$ \\
\hline$Z n T 1$ & Zinc exporter & $\begin{array}{l}\text { Embryonic lethal (E8-E9), transporting maternal zinc } \\
\text { into embryo }\end{array}$ & (Andrews et al., 2004) \\
\hline$Z n T 2$ & Vesicular zinc transporter & Dermatitis due to low zinc in breast milk (in human) & (Chowanadisai et al., 2006) \\
\hline ZnT4 & Vesicular zinc transporter & Lethal milk mutation in mice, suckling pups die & (Huang and Gitschier, 1997) \\
\hline $\mathrm{ZnT5}$ & $\begin{array}{l}\text { Zinc transporter - Golgi } \\
\text { apparatus }\end{array}$ & $\begin{array}{l}\text { Growth retardation, osteopenia, male specific cardiac } \\
\text { sudden death in null mouse }\end{array}$ & (Inoue et al., 2002) \\
\hline
\end{tabular}


Table 3

Phenotypes of Animals With Mutations in Genes Critical for Iron Homeostasis During Development

\begin{tabular}{|c|c|c|c|}
\hline Gene & Functions & Phenotype & Reference \\
\hline & & $\begin{array}{l}\text { Hypochromic, microcytic anemia, } \\
\text { defective erythropoiesis }\end{array}$ & \\
\hline \multirow[t]{5}{*}{ Dmt1 } & Iron transporter (Slc11a2) & & \\
\hline & in Slc1la ${ }^{\mathrm{b}}$ Belgrade rat & & (Touret et al., 2004) \\
\hline & in Slclla $2^{m k}$ microcytic anemia mouse & & (Touret et al., 2004) \\
\hline & in Slc1la2 $2^{-/-}$null mouse & & (Gunshin et al., 2005) \\
\hline & in zebrafish Chardonnay & & (Donovan et al., 2002) \\
\hline Fpn & iron efflux in zebrafish Weisshergst & & (Donavan et al., 2000) \\
\hline Heph & Iron oxidase in sex-linked anemia mouse & & $\begin{array}{l}\text { (reviewed by Andrews, } \\
2000 \text { ) }\end{array}$ \\
\hline \multirow[t]{2}{*}{ Mtfrn } & Mitochondrial iron importer in zebrafish & & (Shaw et al., 2006) \\
\hline & Frascati and null mouse ES cells & & \\
\hline Steap3 & $\begin{array}{l}\text { Endosomal ferric/cupric reductase in null mouse } \\
\text { and } n m 1054 \text { mouse }\end{array}$ & & (Ohgami et al., 2005) \\
\hline$T f$ & Serum iron carrier in $H p x$ mouse & & $\begin{array}{l}\text { (reviewed by Andrews, } \\
2000 \text { ) }\end{array}$ \\
\hline \multirow[t]{2}{*}{ Tfrl } & $\begin{array}{l}\text { Transferrin receptor for iron uptake in zebrafish } \\
\text { Chianti }\end{array}$ & & (Wingert et al., 2004) \\
\hline & & Impaired embryonic development & \\
\hline$A b c b 7$ & Mitochondrial efflux of $\mathrm{Fe}-\mathrm{S}$ substrate & $\begin{array}{l}\text { Embryonic lethal } \sim \text { E6.5 in null } \\
\text { mouse, extraembryonic defect }\end{array}$ & (Pondarre et al., 2006) \\
\hline \multirow[t]{2}{*}{ Fpn } & Iron efflux & $\begin{array}{l}\text { Embryonic lethal } \sim \text { E7.5 in null } \\
\text { mouse, visceral endoderm defect }\end{array}$ & (Donovan et al., 2005) \\
\hline & & $\begin{array}{l}\text { Hypomorphic allele, midgestation } \\
\text { lethal, neurogenesis defects in } \\
\text { Flatiron mouse }\end{array}$ & (Zohn et al., 2007) \\
\hline Fxn & Fe-S cluster assembly & $\begin{array}{l}\text { Embryonic lethal 3E5-E7 in null } \\
\text { mouse (early postimplantation) }\end{array}$ & (Cossee, et al., 2000) \\
\hline Fth1 & Iron storage & $\begin{array}{l}\text { Embryonic lethal ( } 3 \text { E3.5-E9.5) in } \\
\text { null mouse, defective heart } \\
\text { development }\end{array}$ & (Ferreira, et al., 2000) \\
\hline $\operatorname{Irp} 1+\operatorname{Irp} 2$ & Posttranscriptional regulation & $\begin{array}{l}\text { Embryonic lethal blastocyst stage in } \\
\text { double null mouse, iron overload }\end{array}$ & (Smith et al., 2004, 2006) \\
\hline Tfr 1 & Endocytic uptake of iron in mouse & $\begin{array}{l}\text { Embryonic lethal 3E12.5 in null } \\
\text { mouse, impaired CNS, and erythroid } \\
\text { development }\end{array}$ & (Levy et al., 1999) \\
\hline
\end{tabular}

